\title{
Investigation on Effects of Sheep Wool fiber on Properties of C-25 Concrete
}

\author{
Dereje Gelana $^{1 *}$, Getechew Kebede ${ }^{2}$, Lucy Feleke ${ }^{3}$ \\ ${ }^{1}$ Faculty of Civil and Environmental Engineering Construction Engineering and Management Chair \\ ${ }^{2,3}$ Ass prof, Jimma university institute of technology
}

DOI: $10.36348 /$ sjce.2019.v03i06.001 $\quad$ | Received: 15.10 .2019 | Accepted: 22.10 .2019 | Published: 11.11 .2019

*Corresponding author: Dereje Gelana

\section{Abstract}

In developing countries like Ethiopia where concrete is widely used there is a steadily increasing the cost of concrete. This made construction work very expensive, due to less availability of concrete ingredients. In recent years, the use of natural fibers is become increasingly common in the civil engineering sector, as a part of energy-efficient and sustainable trends. Several researches demonstrated good properties of sheep wool fibres which a basis for compressive strength, tensile strength and improve environmental issue. The paper was focus on investigation on effects of sheep wool usage as a concrete composite material in C-25 concrete. The investigation is very important because, at present, the knowledge and the application of sheep wool fibers in this sector are relatively limited in our country. So an attempt has been made to achieve improved strength results using sheep wool fiber in conventional concrete. Experiments were conducted on concrete cubes and beam of various percentages of sheep wool fiber such as $0,0.5,1,1.5$ and $2 \%$ by weight of cement were tested for their workability, compressive strength and flexural tensile strength. The sheep wool were collected from different sources and dipped into salt water for 2 days to make hair surface rough. The wool has been sun dried. The mix ratio for C-25 concrete specimen was done in accordance with ASTM 595 and ACI 544.1R-96. From the study workability of the mix was reduced as percentage of sheep increase. The optimum amount of sheep wool fiber to produce concrete was $1.5 \%$. Using $1.5 \%$ of fiber increase concrete compressive strength, flexural strength and split tensile strength property. It can be concluded that using sheep wool fibered concrete were preferable particularly to improve flexural strength.

Keywords: Sheep Wool fiber; Compressive Strength; Workability; Grade of Concrete.

Copyright @ 2019: This is an open-access article distributed under the terms of the Creative Commons Attribution license which permits unrestricted use, distribution, and reproduction in any medium for non-commercial use (NonCommercial, or CC-BY-NC) provided the original author and source are credited.

$\begin{array}{ll}\text { ACRONYMS } & \\ \text { ACI } & \text { American Concrete Institute } \\ \text { ASTM } & \text { American Society for Testing and Materials } \\ \text { CA } & \text { Coarse Aggregate } \\ \text { CEB } & \text { Compressed earth block } \\ \text { C-25 } & \text { Pascal compressive strength } \\ \text { EBCS } & \text { Ethiopian building code standard } \\ \text { FA } & \text { Fine Aggregate } \\ \text { JIT } & \text { Jimma Institute of Technology } \\ \text { FRC } & \text { Fiber Reinforced Concrete } \\ \text { OPC } & \text { Ordinary Portland cement } \\ \text { BS } & \text { Building Standard } \\ \text { FRP } & \text { Fiber Reinforced Polymer } \\ \text { NFRC } & \text { Natural Fiber Reinforced Concrete } \\ \text { NFR } & \text { Natural Fiber Reinforcement }\end{array}$




\section{INTRODUCTION \\ Backgrounds}

In comparison to normal concrete, fiber reinforced concrete scores higher in toughness, and resistance to impact. Fiber reinforcing has added versatility into concrete so as to overcome its brittleness. Fiber is a small piece of reinforcing material possessing certain characteristics properties. Addition of steel reduced the micro cracks but over a long period, steel gets corroded due to various actions. This made the need for enlightenment of usage of various organic and inorganic fibers which are ecofriendly and economic. Natural fibers can be defined as bio-based fibers of vegetable and animal origin. The use of natural materials in building industry is supposed to reduce the production costs and to contribute to significant improvements of environment quality. The thesis is highlighting the possibility of sheep wool usage in construction engineering, as a part of the most complex concept of eco-friendly materials and green concrete production.

Ethiopia has a diverse indigenous sheep population numbering over 23.6 million. Sheep contribute significantly to farm livelihoods, particularly where crop production is unreliable and where livestock is the mainstay of livelihoods. Fiber type is another major distinguishing feature of sheep breeds in Ethiopia. There are two breed groups: course-wool sheep and short-hair sheep. These breeds have developed this characteristic as an adaptation to their ecological distribution. Coarse-wool sheep are found in cold, sub-alpine environments and short-hair sheep in warmer areas [1].

A Fiber is a small piece of reinforcing material possessing certain characteristics properties. Addition of fibers to concrete influences its mechanical properties which significantly depend on the type and percentage of fiber. The property of fiber reinforced concrete is influenced mainly by the physical and mechanical properties of the fiber. A good fiber should have good adhesion within the matrix and adaptable elasticity modulus. It must be compatible with the binder, which shouldn't be attacked or destroyed in the long term. It should be short, fine and flexible to permit mixing, transporting and placing and also strong enough to withstand the mixing process [2].

Natural fibres present an increasing interest for applications in civil engineering, as in many other sectors such as military, industrial, space craft, and biomedical. The first researches on natural fibres were conducted on their usage in non-structural parts due to their low resistance and moist degradation. Nowadays, besides thermo-acoustical applications, natural fibres are increasingly used as reinforcement for different kinds of composites in building industry, being an alternative to synthetic materials due to their easy availability, renewability, low costs, light weight, high specific strength and stiffness [3].

The science of incorporating one or more materials in concrete to improve strength and satisfy design requirements is not new. Since the $17^{\text {th }}$ Century, man has been known to make composite materials to achieve the desired design strengths. Mostly concrete is reinforced with steel bars. Over the years scientists have been doing research on reinforcing concrete with fibers. The approach of replacing steel by incorporating the natural fibers in concrete is termed as Natural Fiber Reinforced Concrete (NFRC).The use of fiber reinforced concrete can be dated back since 1870 . Since then researchers have been working on concrete reinforced with wood fiber, waste glass, sisal fibers and vegetable fibers such as elephant grass, and many more. In particular, the natural fibers are sometimes used as reinforcement together with steel in concrete so as to reduce cracking and spalling of the structures[4].

\section{Statement of the Problem}

Concrete is relatively brittle, and its tensile strength is typically only about one tenths of its compressive strength. Regular concrete is therefore normally reinforced with steel reinforcing bars. For many applications, it is becoming increasingly popular to reinforce the concrete with small, randomly distributed fibers. Their main purpose is to increase the energy absorption capacity and toughness of the material, but also increase tensile and flexural strength of concrete. In particular, the natural fibers are sometimes used as reinforcement together with steel in concrete so as to reduce cracking and spalling of the structures [4]. Adding something in concrete to improve or increase its tensile capacity is commonly known in construction engineering. For that fiber is most commonly used in construction industries. Normally; various fibers were used in the concrete mix to enhance the tensile strength and resistance recently. In study, using salt water cored sheep wool as fiber reinforced admixture was studied and verified the strength of concrete compared to ordinary Portland cements strength of C-25 concrete using sheep wool as fiber reinforcement admixtures incorporated with the concrete so as to enhance the tensile and other mechanical properties. The study was advances the utility of sheep wool fiber, thereby improving the mechanical properties of Concrete.

\section{Research Question}

- What is the effect of using sheep wool fiber on workability of concrete?

- What is the effect of sheep wool fiber on compressive strength and flexural strength of concrete?

- What is the optimum percentage of sheep wool fiber for concrete production by weight of cement and Sheep wool fiber reinforced concrete? 


\section{OBJECTIVE OF THE STUDY \\ General objective}

The main aim of the study was to investigate the properties of C-25 concrete using sheep wool fiber as fiber reinforced concrete composite material.

\section{Specific Objectives}

- To determine the workability of concrete mixed using sheep wool fiber.

- To determine compressive and flexural tensile strength of concrete casted using water cored sheep wool fiber

- To determine the optimum percentage of sheep wool fiber added to the mix for concrete production.

\section{Significance of the Study}

This study advances the utility of sheep wool fibers, thereby improving the mechanical properties of Concrete. The overall aim my study is to investigate and improve the understanding of the behavior of reinforced concrete casted by sheep wool as fiber reinforced composite will studied and verified the strength of concrete compared to ordinary Portland cements strength of different grade of concrete using sheep wool as fiber reinforcement composite.

Experimental tests will be performed to investigate the behavior of sheep wool fiber in reinforced concrete cube and beam; the load will be loaded until failure. It also known that the output of this study will be added to the existing academic knowledge and enable to understand the subject matter as it paves the way for further investigation related to this. Moreover, it can benefit other parties of the society through; allowing the researcher to gain knowledge on the effect of sheep wool fiber in reinforced concrete, thereby build academic knowledge and provide base for further career improvement, It would also benefit Jimma Institute of Technology (JIT) in attaining its objective as a center of academic excellence and accelerate the national development through provision of problem solving research output to the policy and decision makers.

\section{Scope of the Study}

The study was investigated on improving concrete mechanical property by using fiber by weight of cement as an alternative to improve concrete tensile strength and to alleviate environmental impact. The scope of the study is determining the effect of sheep wool fiber on concrete strength. Sheep wool is taken out as waste in different countries including Ethiopia it can regrow after cutting for various purposes; hence they pose an environmental challenge mostly around slaughter house because it is non-decomposable material. Sheep wool is easily available in cheap cost. So it can be as a fiber in C-25 concrete, to encourage practice of using wastes in different area, to reduce environmental problem, as it is good in tension improve concrete flexural strength, reduce crack propagation this help to increase durability of structure, improve concrete impermeability, reduce micro cracks and my study can be used for another studies as a reference.

\section{CHAPTER TWO}

\section{LITERATURE REVIEW General}

The sheep is a quadropedal, ruminant mammal typically kept as livestock. Numbering a little over one billion, domestic sheep are also the most numerous species of sheep. Sheep are raised for fleece, meat and milk. A sheep's wool is the widely used animal fiber, and is usually harvested by shearing. Wool has several qualities that distinguish it from hair or fur: it is crimped and elastic [5]. Wool is produced by follicles which are small cells located in the skin. Medullated fibers are nerve fibers which share nearly identical characteristics to hair and are long but lack crimp and elasticity. Kemp fibers are very coarse and shed out [6]. Wool ignites at a higher temperature than cotton and same synthetic fibers. It has a lower rate of flame spread, a lower rate of heat release, a lower heat of combustion and does not melt or dip [7].

There are many additives to make concrete better, set faster, set slower, make stronger and reduce corrosion. The Romans discovered that adding volcanic ash produced a concrete which would set under water. The Romans also knew that adding horse hair made concrete less liable to crack as it set, and that adding blood made it more frost-resistant. Hair is used as a fiber reinforcing material in concrete for the following reasons:

- It has a high tensile strength which is equal to that of a copper wire with similar diameter.

- Hair, a non-degradable matter is creating an environmental problem so its use as a fiber reinforcing material can minimize the problem.

- It is also available in abundance and at a very low cost. iv. It also reinforces the mortar and prevents it from spalling [8].

Fibers are class of hair-like materials that are in discrete elongated pieces, Similar to pieces of thread [9]. They can be spun into filaments, thread or rope. They can be used as a component of composite materials. Fiber can be classified into two main groups, which are man-made fiber and natural fiber. In general, natural fibers can be subdivided as to their origin such as plants, animals, or minerals; while man-made fibers can be subdivided to synthetic and natural polymers.

FRC is cement based composite material that has been developed in recent years. It has been successfully used in construction with its excellent flexural-tensile strength, resistance to splitting, impact resistance and excellent permeability and frost resistance. It is an effective way to increase toughness, shock resistance and resistance to plastic shrinkage 
cracking of the mortar. Fiber is a small piece of reinforcing material possessing certain characteristic properties [10].

\section{Property of sheep wool}

Wool is produced by follicles which are small cells located in the skin. Medullated fibers are nerve fibers which share nearly identical characteristics to hair and are long but lack crimp and elasticity. Kemp fibers are very coarse and shed out [6]. Wool fibers readily absorb moisture, but are not hallow. Wool can absorb almost one third of its weight of water. Wool ignites at a higher temperature than cotton and same synthetic fibers. It has a lower rate of flame spread, a lower rate of heat release, a lower heat of combustion and does not melt or dip. Although sheep wool can't be kept smooth while dipping in salt water is a best property which means that the surface tension of hair increases by dipping sheep wool in salt water, hence gives greater bond strength as author used the wool as fiber reinforced admixture. As it is oven dried these will be less chance of bio-degradation [11].

Dipping wool in acetone solution which removes impurities, but the present study [7] says, use of acetone for washing wool induces smoothening of dermis coat present on surface of wool, which results in lowering of bonding strength of admixtures. Acetone will smoothen the surface of wool hence reduces surface tension. The [7] has experimented by dipping wool in salt water to increase its surface tension and bonding strength of admixtures to experience different results.

The main ones are wool grease, water-soluble material derived from perspiration and contaminants such as dirt and vegetable matter which can be removed by washing. Clean wool belongs to a group of proteins known as keratins. It has been estimated that wool contains more than 170 different proteins not uniformly distributed throughout the fibre. This heterogeneous composition is responsible for different physical and chemical properties of the various regions of wool. The proteins in wool are composed of amino acids. A wool fibre can be considered as a biological composite consisting of regions that are both chemically and physically different. Even after the natural wool grease has been removed by scouring with a detergent, wool fibres are relatively difficult to wet compared with other textile materials. This natural water repellency makes wool fabrics 'shower-proof ' and this property is the result of a waxy, hydrocarbon coating that is chemically bound to the surface. The first step in wool processing, regardless of the end product, is washing in hot, soapy water (i.e. scoured) to remove dirt, grease and other impurities. The scouring water is normally about $65^{\circ} \mathrm{C}$, which is hot enough to dissolve the wax (i.e. lanolin), and detergent is added to help remove the dirt from the fibres and to emulsify the wax so it doesn't stick back onto them. This stage is also the stage where the chemical agents (according to the end usage) are applied to the wool. Clean wool contains $82 \%$ of the keratinous proteins, which contain high concentration of sulphur $(3 \%)$. The amount of sulphur in the keratin determines the strength of wool because of strong disulfide bonds. Keratin does not dissolve in cold or hot water and does not breakdown into soluble substances [12].

Using sheep wool as fiber reinforcement as concrete admixture gave good percentage of increment in both compressive strength and flexural strength of concrete, but as the grade of cement increases the percentage of increment in strength gradually reduces. By using wool dipped in salt water as an admixture, withstands more compressive and flexural strength than ordinary Portland cement [7].

\section{Property of fiber reinforced concrete}

Concrete is so far the most important building material and its consumption is increasing in our countries and all over the world. The disadvantages of concrete is its brittleness, i.e. relatively low tensile strength and poor resistance to crack opening and propagation. For the development of concrete the reinforcement with dispersed fibers plays an important role [13].

Fiber reinforced concrete is a composite material containing fiber in the cement matrix in an orderly manner or randomly distributed manner its properties would obviously depend upon the efficient transfer of stress between matrix and the fibers, which is largely depend on the type of fiber, fiber geometry, fiber content and distribution of the fibers, mixing and compaction techniques of concrete, size and shape of the aggregate [14].

The addition of any type of fibers to plain concrete reduces the workability. Concrete mixtures containing fibers possess very low consistencies; however, the place ability and compact ability of concrete is much better than reflected by the low consistency. Fibers do not do anything to stop the first crack; it slows down the propagation of cracks. Small micro fibers stabilize the micro cracks and increase the strength reducing the porosity of the cement paste as well increases the strength [15]. 


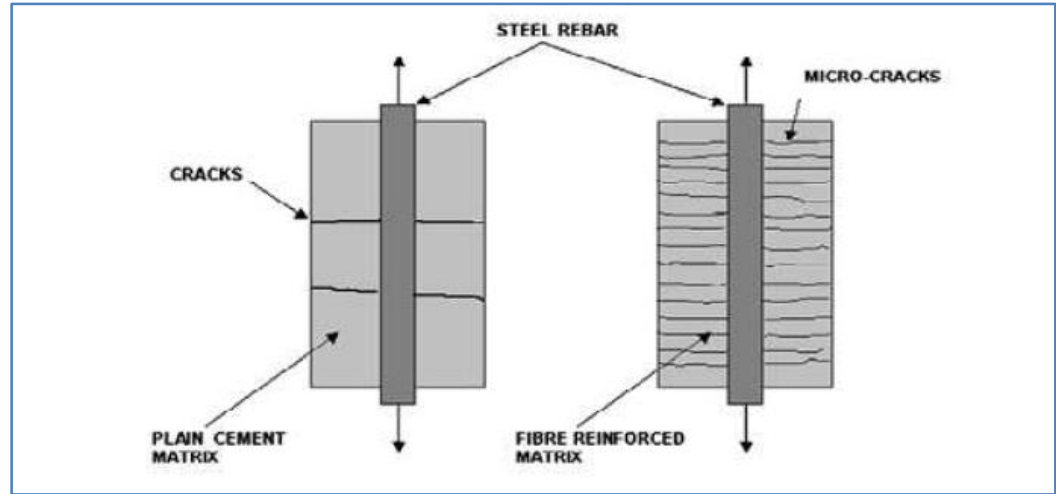

Fig-2.1: Crack pattern in reinforced concrete (RC) and fibers reinforced concrete (FRC) elements subjected to tension (Brandt A, 2008)

The fine fibers control opening and propagation of micro cracks as they are densely dispersed where as long fibers control large cracks and contribute to increase the final strength of fiber reinforced concrete (FRC).

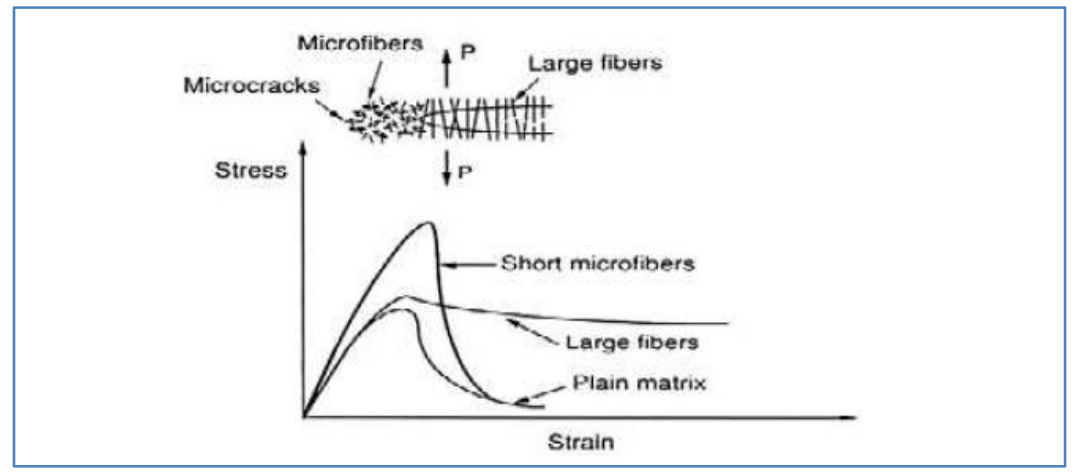

Fig-2. 2: Stress strain diagram for large and short fibers [16].

The use of some of the best known natural fibers was mostly limited to making things like ropes, mats and fabrics. Only recently did scientist start carrying out researches on the use of fibers, and of cement composites made with these fibers was undertaken. The results indicated that these natural fibers can be successfully used in light concrete structures for walls, roofing and low-loaded pavements. Subsequently, production and processing was started in countries in Asia, Africa and Central America [4].

However, the application of these materials in the construction industry is still quite minimal due to a lack of understanding of how to increase the fiber durability. The fiber composites undergo an aging process in humid environments in which they may suffer a reduction in post-cracking strength and toughness. This durability problem is associated with an increase in fiber fracture and a decrease in fiber pull-out due to the weakening of the fibers by a combination of alkali attack, fiber mineralization due to migration of hydration products to lumens and to the middle lamella, and volume variation in these fibers due to their high water absorption. A durable cement composite reinforced with natural fibers should be produced in the construction industry, and research is underway to find suitable admixtures. It has also been proven that the development of durable cementations composites reinforced by sisal fiber for semi-structural and structural purposes is possible [17].

Even though, the paper published on Material design and characterization of high performance pervious concrete were proportioned with various matrixes and compressive and flexural strength test were conducted. This research results show that compressive strength and elastic modulus increase by up to $150 \%$ and $100 \%$ respectively. In this research highlight that the development and characterization of high performance pervious concrete aiming at improved mechanical and advanced durability properties. It was observed that incorporation of appropriate amount of fibre reinforcement could further improve the durability of pervious concrete [18].

The test conducted on some properties of fibre reinforced no fine concrete. The paper focuses on studying the mechanical characteristics of polypropylene and carbon fiber reinforced no fine aggregate concrete containing a different percentage of fibre. Tests to determine workability, density, compressive strength, split tensile strength and modulus of rupture were carried out. It was found that pervious concrete mixes with fibres have higher density than normal pervious concrete mixes containing polypropylene and carbon. The test results also 
indicated that the inclusion of fibre to the pervious concrete mixes increases compressive strength, split tensile strength and modulus of rupture [19].

Comparative study on strength and permeability of pervious concrete by using nylon and polypropylene fiber used in various proportions i.e., $0.1 \%, 0.15 \%, 0.2 \%$ etc. of volume of concrete. Also the paper says about types of fibres help to increase the properties of pervious concrete. The fibres are glass fibres, natural fibres like flax, hemp, kenaf, jute, banana and coir, synthetic fibres like nylon, polypropylene, carbon, polyester etc. Natural reinforcing materials can be obtained at low cost and low levels of energy using local manpower and technology. The test result also indicated that the compressed strength of nylon and polypropylene fiber up-to $0.2 \%$ of used result get increased. And the permeability of fibre mixed pervious concrete is increased as comparison to the plain pervious concrete [20].

\section{Advantages and Disadvantages of natural fiber reinforced concrete}

\section{Advantages [21]}

- Are more resistant to cracking and reduce internal forces by blocking microscopic cracks from forming within the concrete.

- Lighter than traditional concrete and as a result substantial weight saving can be realized using relatively thin NFRC sections having the equivalent strength of thicker Plain concrete sections.

- Has a unique crack behavior in that it maintains a crack width below $100 \mu \mathrm{m}$ when loaded beyond the elastic range.

- Has an advantage over steel since corrosion does not take place at its interface with Concrete .Suitable for structures where corrosion is to be avoided at maximum.

\section{Disadvantages}

- The main disadvantage of NFRC is in the placement of the fibers in concrete mix as sometimes balling occurs.

- The major concern in their larger scale application is still the lack of the long term durability of the natural fibers in the high alkaline environment of the Portland cement matrix.

\section{Material Compositions for FRC \\ Sheep wool fiber}

FRC comprises two components; namely the matrix component considered as the conventional concrete and the fiber component. The compositions of the concrete matrix component consist of cement, aggregate, water and in some cases additives are incorporated for a particular interest. The relative amount of these constitutive materials depends on several factors like workability, strength, durability and cost of the final product [22].

\section{Cement}

Conventionally, cement is a powdered material that serves as a binder in mortar or concrete after reactions of lime or lime compounds have taken place with appropriate medium-usually water. Portland cement is one of such materials, composed largely of calcium and aluminum silicates, in which the former upon reaction with water produces the new compound capable of imparting stone like quality to the mixture. While the specific gravity of Portland cement ranges from 3.12 to 3.16 , its unit weight varies with the degree of compaction [23].

\section{Aggregates}

Aggregate is one component of FRC, which is connected into a cohesive whole by means of binding materials-the cement paste. Aggregates are usually inert materials or artificially manufactured from industrial products, which are added to cement paste in order to improve strength, durability and structural performance of concrete. Those aggregates from natural sources are conventionally adopted as concrete materials, and those from artificial ones are either light in weight or high density, developed for specific structural applications and also for solving part of the problems related to the shortage of naturally occurring aggregates. Aggregates can be explained with respect to petrological (rock type), mineralogical, and geological examinations, of which the latter two basis are of great helpful in recognizing properties and qualities of aggregates for our purpose [24].

The physical and mechanical properties of aggregate (density, strength, elasticity, toughness, hardness etc.) depend largely on its composition, texture and structure. Such properties of aggregate and their contribution on its physico-mechancical properties, and also their influence on the strength of concrete are available in literatures [23, 24]. The mechanical strength, bond characteristics and absorption capacity of aggregate are some of the factors that influence the strength of concrete. The bond is due, in part, to the interlocking of aggregate and to the paste that is attributed to the surface of the former. A rough surface and mineralogical heterogeneous particles result in better bond [24].

\section{Water}

In the production of concrete, water is used for mixing, washing of aggregate and curing of the final concrete product. Mixing water should contain no substances that can have an appreciably harmful effect on the process of hydration or upon the durability of concrete during its service period. Water having appreciable amounts of impurities-silt, oil, acids, alkalies, salts of alkalies, organic matter and sewage may have an injurious effect upon concrete [24]. 
The reduction in strength of concrete through the use of water suspected of undesirable substances could be as high as $10 \%$ [25]. The effect of same amount of impurities in water for washing aggregate is much greater than that of mixing water. Such water if used for washing aggregate causes deleterious coatings (silts, salts or organic materials) on the surface of aggregate particles. Water containing sufficient amount of acidic or organic substances should be regarded with suspicion to be used for curing of concrete. Nevertheless, silt or oil in curing water does not appear to have harmful effects except for the possibility of discoloration [24].

Above all, the limiting amount of deleterious substances to be employed in making natural fiber reinforced concrete should not be underestimated, as the natural fibers by themselves are highly susceptible to such impurities. ASTM C 1116-02 gives the limiting values of deleterious materials in water for the FRC.

\section{Mix Design of the FRC}

Mix design is the process of determining the relative quantities of the ingredients of concrete taking in to account the availability of materials and their cost, requirements of placing and finishing the fresh concrete, and properties of the hardened concrete [26]. The mix design of FRC materials is quite similar to that of the conventional concrete except the inclusion of reinforcing fibers-the relative amount of which is governed by workability of the fresh concrete and the properties of the hardened concrete [27].

The economic aspect of concrete mix in construction depends primarily on the cost of material other than on cost of labor and related factors as the latter two, although take larger part of the total cost, do not make differences between different concretes.

Hence, concrete mix design aims at compromising between the costs of materials associated with the amount needed in the desired mix and the production of appropriate workability so as to keep placement and finishing costs at a minimum while securing quality in the finished product [24]. In practice, proportion of cement, fine aggregate and coarse aggregate is expressed in terms of parts or ratios with cement as a reference-usually taken as unity.

The content of water, fiber and other entrained air or admixtures is expressed in terms of water cement ratio, fiber-matrix ratio and percentage ratio respectively. In any case, the basis of proportioning should be stated along with the parts or ratios: may be either by weight or by volume (absolute or bulk).

In ordinary concrete mix, it is reasonable to assume that concrete consists essentially of inert mineral aggregate and cement-water paste which is the active ingredient controlling workability, strength, permeability and drying shrinkage [24].

Water-cement ratio, cement content or cementaggregate ratio, gradation of the aggregate and consistency of the paste are among the variables to be manipulated in the mix design of concrete [24]. In addition, the content and morphology of fiber in FRC have to be taken into account while mix design is carried out.

All the aforementioned variables are so interrelated that one cannot choose or manipulate arbitrarily; usually two or more of the variables are specified and others are adjusted to give the intended requirements dictated by general experience with regard to structural design considerations, durability and condition of placing.

Different methods of mix design of concrete have been investigated so far [24] arbitrary proportions, proportioning by maximum density of aggregate, proportioning by surface area of aggregate, proportioning by fineness modulus of aggregate, proportioning by void content ratio and mortar voids, and proportioning by void contents of coarse aggregate. There are no separate methods of proportioning devised for the mix design of FRC. Instead, the relative amount of cement, aggregate and water is determined based on the usual methods of proportioning, then follows the determination of the fiber content based on the required workability and strength of the FRC [24,27].

\section{Test Methods for FRC}

The process of testing methods for FRC is not a dead end and the issue is still in progress. Around in the 1970s, there have been some organizations involved in the development of test methods for FRC. ACI Committee 544 and ASTM provide the following suggestions for rheology, compression and flexural test of FRC [26].

\section{Compressive Strength}

Compression test for FRC can be conducted as per the conventional concrete stipulated in ASTM C 39, C 192 and C 469.

\section{Flexural Strength}

The general test procedures in ASTM C 42, C 78, C 293 and C 683 are applicable with the subsequent constraints. The flexural behavior of FRC can be determined by evaluating the modulus of rupture, firstcrack strength and flexural toughness indices. For this particular research on BFRC the modulus of rupture evaluated for each maximum flexural load from test result. 


\section{CHAPTER THREE}

\section{MATERIAL AND RESEARCH METHODOLOGY \\ Material used}

Materials that have been used are cement, aggregate, water and sheep wool fibers with specification of conventional concrete. In reference to this study, conventional concrete signifies the usual concrete which contains cement, water and aggregates as a basic constituents. To construct sample with sheep wool fiber concrete, ordinary Portland cement, sand, coarse aggregate, mixing and placing equipment's were required to construct sample beam and cylinder. For the experimental set up universal testing machines was also used in order to test the flexural, compressive and split tensile strength of the sheep wool reinforced concrete sample.

\section{Data requirement}

For the experimental analysis of the cubes and beams samples constructed by the natural sheep wool fiber reinforced concrete, the available universal testing machine was used for finding the properties; Compressive strength, Flexural strength and Split tensile strength.

\section{Research design}

In order to attain the required specific objectives; both quality and quantitative with descriptive experimental analysis type of the study were applied to the research. The qualitative explains the quality of materials used while the quantitative shows the numerical amount of each material used and in addition the descriptive method means the way fibers were treated to made the composite concrete in constructing model.

An experimental study has been implemented to manipulate the independent variables, and then justified for the natural fibers based on the experimental result. Finally, recommendation was given based on the approaching experimental results.

\section{Study variables}

\section{Independent variables}

- Fiber Properties of Sheep wool fibered C-25 concrete

\section{Dependent Variables}

- Workability of C-25 concrete mixed using sheep wool fiber

- Compressive strength of C-25 concrete casted using sheep wool fiber

- Flexural strength of C-25 concrete casted using sheep wool fiber

- $\quad$ Split tensile strength of C-25 concrete casted using sheep wool fiber

- Optimum percentage of sheep wool

\section{Study design}

The total number of populations that considered in the study was the numbers of cubes and beam used as a control for the experiment and the number of composite samples of natural sheep wool fibers. Based on percentage of fibre content $(0 \%, 0.5 \%$, $1 \%, 1.5 \%$ and $2 \%$ ) in the concrete the samples of three were casted for each $7^{\text {th }}$ and $28^{\text {th }}$ day test.

Table-3.1: Sample population

\begin{tabular}{|c|r|r|r|r|r|}
\hline & \multicolumn{6}{|c|}{ Total number of sample for $\mathbf{7}^{\text {th }}$ and $\mathbf{2 8}^{\text {th }}$ day } & Control \\
\hline Sample & $0.5 \%$ & $1 \%$ & $1.5 \%$ & $2 \%$ & 0 \\
\hline Cubes & 6 & 6 & 6 & 6 & 6 \\
\hline Beams & 6 & 6 & 6 & 6 & 6 \\
\hline
\end{tabular}

Totally 30 samples of flexural beam, 30 samples of cubes are casted and tested.

\section{Data collection process}

The wool used for the thesis is Awassi sheep wool or sheep type found in Menz area of Ahmara regional state. After fiber is collected another data is gained from laboratory test conduct on concrete ingredients. The quality of the data assured through replicate the samples by using standard operating procedures. Check the accuracy and validity of data instrument calibration and verification. In addition, the researcher will give attention during material preparation and testing activities.

\section{The process of fiber preparation}

The raw material is collected from Menz, located at distance of $130 \mathrm{~km}$ from Addis Ababa from northern direction.

The wool used for this research is sheared from sheep and brought to laboratory and follow the following process to use.

- Collect the wool and bring to laboratory

- Soak the wool at least for two days in salt water

- Dry on sun for two days and hand peel

- Cut the fiber to maximum of $5 \mathrm{~cm}$ length

\section{Material Design and preparation}

The study concrete mix design was according to ACI 211.1. For different percentages of fiber, mix 
five C-25 grade concrete including the control which is used as a comparison with the other different percentage fibered concrete.

The sheep wool is collected from different sources and they are dipped into salt water in the ratio of 35 grams per liter of water for 2 days to make hair surface rough and it helps in good bond strength with concrete. The soaked wool is kept for drying under sunlight for one day.

The mix proportion is constant throughout the mix; by varying the fiber percentage the fresh and hard concrete was different. Investigate this variation by comparing with the control mix. Check the workability, compressive strength, flexural and split tensile strength of fibered concrete. According to ASTMC-192/C192M [25], test ages often used are 7 and 28 days for tensile. Therefore, test conduct at the age of 7 and 28days tensile strength test on concrete cubes, and then study the strength loose or gain by comparing with the control mix.

The materials like cement, coarse aggregate, fine aggregate and salt used for the study is delivered to the laboratory from different area of Jimma town and surround but the sheep wool fibers from Menz for laboratory purpose because it was difficult to get the right quality of sheep wool and since commercial material there. Dipping wool in acetone solution which removes impurities, but the present study author says, use of acetone for washing wool induces smoothening of dermis coat present on surface of wool, which results in lowering of bonding strength of admixtures. Acetone will smoothen the surface of wool hence reduces surface tension. The experiment was done by dipping wool in salt water to increase its surface tension and bonding strength of admixtures to experience different results.

\section{Measurement of Ingredients and Mixing Procedures \\ The measurement of cement, aggregates and fiber is measured by weight with accuracy of $0.1 \mathrm{~g}$ balance according to calculated mix design, and water was measured by volume under ambient temperature. Before measuring the coarse aggregate Split it by splitter to dispense all size equally and also quartering sheep wool fiber before measuring to disperse all size and diameter equally.}

After that the weight coarse aggregate and first add on the mixing machine and the fine aggregate was added after the coarse aggregate and then the well prepared dipped in salt water and oven dried sheep wool fiber is added next of that to allow mix properly with the ingredients and cement is added next to sheep wool fiber and dry mixed for two minutes. Then, water was added to the dry mixed concrete ingredients and mix for three more minutes. Mixing of concrete by varying percentage of sheep wool by weight of cement
$(0,0.5,1,1.5$ and $2 \%)$ and the ingredients coarse aggregate, fine aggregate and water are constant for all C-25 concrete mix. The mixer produces concrete enough to cast four cylinders for each percentage of sheep wool fiber. After pouring the well mixed concrete on the prepared clean area immediately test the workability by using slump cone. Then cast the prepared lubricated Standard cast iron cylinder moulds of size $20 \mathrm{~cm} \times 15 \mathrm{~cm}$ for split tensile strength test by compacting in to three layers using steel rod of $25 \mathrm{~mm}$ diameter striking 25 times each layer and finally compact by hammer in using rubber hammer. Before finishing the surface with trowel ensure the full compaction thru compacting for 30 seconds by hand. Should be finish before 15 minutes.

Remove the mold after $24 \mathrm{hrs}$ then bold the marks by using marker after the mark dry cur it on water bowel placed at dark place for the next 7 , and 28 days. The concrete mechanical properties were tested after the curing day of 7 , and 28 days.

\section{Material Characterization \\ Tests on coarse aggregates}

Coarse aggregates of a normal weight and with a maximum diameter of $20 \mathrm{~mm}$ were used. The larger $20 \mathrm{~mm}$ coarse aggregates would occupy the larger volume in the cube mould of and lowers the surface area to volume ratio hence improper binding leads to segregation. The most important factor is to ensure uniform dispersion of the fibers and to prevent segregation or balling of the fibers during mixing. Segregation or balling during mixing is affected by many factors, which can be summarized as follows:

- Aspect ratio ( $1 / \mathrm{df})$, which is most important

- Volume percentage of the fiber

- Coarse aggregate size, gradation, and quantity

- Water/cementitious materials ratio and the method of mixing

A maximum aspect ratio of $1 / d f$ and fiber content in excess of $2 \%$ by weight makes it difficult to achieve a uniform mix. Although conventional mixing procedures was used. Where $l$ is the fiber length and $d f$ is the fibre diameter.

\section{Determining the amount fiber used in the concrete}

The amount of fiber added to concrete mix was measured as a percentage of the total volume of the composite (concrete and fiber) termed volume fraction (Vf). Vf typically range from 0.1 to $3 \%$. Aspect ratio $(1 / d)$ is calculated by dividing fiber length (l) by diameter (d). Increase the aspect ratio of the fiber usually segments the flexural strength and toughness of the matrix. However, fibers which are to long tend to ball in the mix and create workability problem. From some recent research pointed out that the micro fibers are better in impact resistance compared with the long fibers [20]. 
The strength of composite largely depends on the quality of fibers used in it but increases in the volume of fibers, increase approximately linearly, the tensile strength and toughness of the composite. Use of higher percentage of fiber is likely to cause segregation and harshness of concrete and mortar.

\section{Determining aspect ratio of fiber}

Another important factor which influences the properties and behavior of the composite is aspect ratio of the fiber. Increasing the aspect ratio of the fiber usually segments the flexural strength and toughness of the matrix Fiber Reinforced Concrete can be defined as a composite material consisting of mixtures of cement, mortar or concrete and discontinuous, discrete, uniformly dispersed suitable fibers [20]. A numerical parameter, describing fiber as its aspect ratio is defined as fiber length divided by an equivalent fiber diameter $[1 / \mathrm{d}]$. Typical aspect ratio [1/d] is range from 30 to 150 $[1]$.

\section{Orientation of fibers}

One of the differences between conventional reinforcement and fiber reinforcement is that in conventional reinforcement, bars are oriented in the direction desired while fibers are randomly oriented.

\section{Mixing of fibered concrete}

Mixing of fiber reinforced concrete needs careful conditions to avoid balling of fibers, segregation and in general the difficulty of mixing the materials uniformly. Increases in the aspect ratio and volume percentage of fiber intensify the difficulties and balling tendency.

It is important that the fibers are dispersed uniformly throughout the mix; this can be done by the addition of fibers before the water is added.

\section{Test on Ordinary Portland cement}

Type of Cement used in this experiment was commercially available Dangote Ordinary Portland cement (OPC) with Cement Grade of 42.5R that was from in Addis Ababa. This cement complies with the requirements of Ethiopian Standards, ES C.D5 201 and ES 1177-ICEM 1/42.5R [28]. The specific gravity of the Dangote OPC was known to have 3.15. Test conducted on cement were consistency test, initial setting time and final setting time.

\section{Normal consistency test}

Normal consistency of cement used for the study was tested by Vicat apparatus with a needle of 300gm according to ASTM C 187 and also the procedure was by following the standard.

\section{Setting time test}

The initial setting time of the paste was determined by the duration of $25 \mathrm{~mm}$ penetration of Vicat needle into the paste in 30 seconds after it has been released while the final setting time was determined by measuring the time related to zero penetration of the needle into the paste.

\section{- Test on Fine aggregate}

River sand from Gambella conforming to specific gravity of 2.66 and fineness modulus of 3.05 was used in this study. Test conducted on fine aggregate according to ASTM were sieve analysis, water absorption, unit weight, specific gravity, moisture content, silt content and determination of organic impurity.

\section{Sieve analysis}

The researcher use round meshes of size $9.5 \mathrm{~mm}, 4.75 \mathrm{~mm}, 2.36 \mathrm{~mm}, 1.18 \mathrm{~mm}, 600 \mu \mathrm{m}, 300 \mu \mathrm{m}$, $150 \mu \mathrm{m}$ and $75 \mu \mathrm{m}$ in descending order. It used to determine the grading, fineness modulus, coarseness and uniformity of aggregates, the study used $500 \mathrm{gm}$ fine aggregate according to ASTM C33/C33M.

\section{Water absorption and specific gravity}

The specific gravity test of the fine aggregate was done by using two different pycnometers and takes the average for each test use $500 \mathrm{gm}$. of oven dried fine aggregate.

\section{Unit weight}

Through this test determine the average loss unit weight and average compacted unit weight of fine aggregate.

\section{Moisture content}

The moisture content of fine aggregates was done on two samples of each weighted $500 \mathrm{gm}$. Oven drying the fine aggregate for $24 \mathrm{hrs}$ with $110^{\circ} \mathrm{C}$. Then calculate the moisture content by the following formula.

\section{Silt content}

Take sample of sand from the sand that's used though out the test and adds to cylinder that's prepared for this test and then add water to it then shake it well. Measure the total volume of sample and the silt lay on the sample then determine the percentage of silt.

\section{Coarse Aggregate}

For all the concrete mixes, the same coarse aggregate was used. Coarse aggregates of a normal weight and with a maximum diameter of $20 \mathrm{~mm}$ were used for the moulds size of $150 \times 150 \times 150 \mathrm{~mm}$

\section{Sieve analysis or gradation}

For gradation test of coarse aggregate use 16 $\mathrm{kg}$ of coarse aggregate for two samples. The range of sieves used was between $75 \mathrm{~mm}$ to $4.75 \mathrm{~mm}$.

\section{Water absorption and specific gravity}

For this test take two samples of coarse aggregate, each weight $4 \mathrm{~kg}$ of coarse aggregate was submerged in to water for 24 hours. Then after $24 \mathrm{hrs}$ 
the aggregate were taken out and their surface was dried using a towel to remove the excess moisture. Then determining their masses, the aggregates were carefully immersed into a basket filled with water, and then measure volume of the displaced water.

\section{Unit weight}

Under this study determine the average value of loose unit weight and compacted unit weight of coarse aggregate.

\section{Moisture content}

The progress is the same as the fine aggregate but for this test take $2 \mathrm{~kg}$ of coarse aggregate for each two samples then dry it on oven for $24 \mathrm{hrs}$. Then calculate the moisture content by using the following equation.
Excess fines in coarse aggregates were removed by sieving through $4.75 \mathrm{~mm}$ sieve to confirm as per requirements. Fines contain many impurities and results in strength loss in the concrete and increase the surface area for water absorption increasing the characteristics of the mix.

Therefore, there is a need to sieve the aggregates to reduce the amount of fines. For the determination of the specific gravity, absorption capacity, and compacted unit weight of aggregates, the general procedures outlined in Table A-1 of AppendixA was applied in the laboratory and the results are shown in Table 3.3

Table-3.2 Specific Gravity, Absorption Capacity and Unit Weight of Aggregates

\begin{tabular}{|l|l|l|l|l|l|l|}
\hline & $\begin{array}{l}\text { Bulk specific } \\
\text { Gravity }\end{array}$ & $\begin{array}{l}\text { Bulk specific } \\
\text { Gravity (SSD) }\end{array}$ & $\begin{array}{l}\text { Apparent } \\
\text { Specific gravity }\end{array}$ & $\begin{array}{l}\text { Absorption } \\
\text { Capacity (\%) }\end{array}$ & $\begin{array}{l}\text { Unit weight } \\
\text { (kg/m3) }\end{array}$ & $\begin{array}{l}\text { Moisture } \\
\text { Content (\%) }\end{array}$ \\
\hline Gravel & 2.66 & 2.69 & 2.75 & 1.26 & 1726 & 0.76 \\
\hline Sand & 3.39 & 2.44 & 2.51 & 2.04 & 1565 & 2 \\
\hline
\end{tabular}

\section{Water}

Check the water taste and odor because the quality of the water has impact on concrete production. It affects setting of the cement, strength of the concrete, form it layer and also it may cause corrosion of reinforcement. So, before mixing check the quality of water.

In this research, use tap water from the laboratory of JIT at room temperature was used for all mixes. And a constant water cement ratio of 0.55 was used.

\section{Concrete Mix design}

In the study five different types of mix design was prepared based on percentage of sheep wool fiber by weight of cement $(0 \%$ as a control mix and other percentage of addition by weight of cement was $0.5,1$, $1.5 \& 2 \%$ ). The quantity of concrete materials was calculated by using the physical properties of the materials.

Table-3.3 Concrete Mix -Design for $1 \mathrm{~m} 3$ of concrete

\begin{tabular}{|l|l|l|}
\hline Percentage of waste human hair & Parameter & Quantity \\
\hline \multirow{5}{*}{$0 \%$ (sheep wool) control } & Water & $503.7(\mathrm{~kg})$ \\
\cline { 2 - 3 } & Cement & $550(\mathrm{~kg})$ \\
\cline { 2 - 3 } & Sheep wool & 0 \\
\cline { 2 - 3 } & Fine aggregate & $1.23 \mathrm{~m}^{3}$ \\
\cline { 2 - 3 } & Coarse aggregate & $2.37 \mathrm{~m}^{3}$ \\
\hline \multirow{5}{*}{ \%(sheep wool) control } & Water & $503.7(\mathrm{~kg})$ \\
\cline { 2 - 3 } & Cement & $550(\mathrm{~kg})$ \\
\cline { 2 - 3 } & Sheep wool & 0.5 \\
\cline { 2 - 3 } & Fine aggregate & $1.23 \mathrm{~m}^{3}$ \\
\cline { 2 - 3 } & Coarse aggregate & $2.37 \mathrm{~m}^{3}$ \\
\hline \multirow{5}{*}{$1.5 \%$ (sheep wool) control } & Water & $503.7(\mathrm{~kg})$ \\
\cline { 2 - 3 } & Cement & $550(\mathrm{~kg})$ \\
\cline { 2 - 3 } & Sheep wool & 1 \\
\cline { 2 - 3 } & Fine aggregate & $1.23 \mathrm{~m}^{3}$ \\
\cline { 2 - 3 } & Coarse aggregate & $2.37 \mathrm{~m}^{3}$ \\
\hline & Water & $503.7(\mathrm{~kg})$ \\
\cline { 2 - 3 } & Cement & $550(\mathrm{~kg})$ \\
\cline { 2 - 3 } & Sheep wool & 1.5 \\
\cline { 2 - 3 } & Fine aggregate & $1.23 \mathrm{~m}^{3}$ \\
\cline { 2 - 3 } & Coarse aggregate & $2.37 \mathrm{~m}^{3}$ \\
\hline \multirow{5}{*}{ \%ool) control } & Water & $503.7(\mathrm{~kg})$ \\
\cline { 2 - 3 } & Cement & $550(\mathrm{~kg})$ \\
\cline { 2 - 3 } & Sheep wool & 2 \\
\cline { 2 - 3 } & Fine aggregate & $1.23 \mathrm{~m}^{3}$ \\
\cline { 2 - 3 } & Coarse aggregate & $2.37 \mathrm{~m}^{3}$ \\
\hline & & \\
\hline
\end{tabular}


Table-3.4: Mixture constituents of the various concrete mix for cubes samples

\begin{tabular}{|l|l|l|l|l|l|l|}
\hline Description & $\begin{array}{l}\text { No of } \\
\text { samples }\end{array}$ & $\begin{array}{l}\text { Cement } \\
(\mathbf{k g})\end{array}$ & $\begin{array}{l}\text { Fine } \\
\text { aggregate (kg) }\end{array}$ & $\begin{array}{l}\text { Coarse } \\
\text { aggregate (kg) }\end{array}$ & $\begin{array}{l}\text { Fiber } \\
\text { content (kg) }\end{array}$ & $\begin{array}{l}\text { Water } \\
\text { (Ltrs) }\end{array}$ \\
\hline Control concrete & 6 & 10.04 & 17.93 & 30.24 & 0 & 4.58 \\
\hline $\begin{array}{l}\text { Mix with 0.5\% of fiber } \\
\text { by total weight }\end{array}$ & 6 & 10.04 & 17.93 & 30.24 & 0.05025 & 4.58 \\
\hline $\begin{array}{l}\text { Mix with 1\%of fiber by } \\
\text { total weight }\end{array}$ & 6 & 10.04 & 17.93 & 30.24 & 0.1005 & 4.58 \\
\hline $\begin{array}{l}\text { Mix with 1.5\%of fiber } \\
\text { by total weight }\end{array}$ & 6 & 10.04 & 17.93 & 30.24 & 0.151 & 4.58 \\
\hline $\begin{array}{l}\text { Mix with 2\%of fiber by } \\
\text { total weight }\end{array}$ & 6 & 10.04 & 17.93 & 30.24 & 0.201 & 4.58 \\
\hline
\end{tabular}

Table-3.5: Mixture constituents of the various concrete mixes for beam samples

\begin{tabular}{|l|l|l|l|l|l|l|}
\hline Description & $\begin{array}{l}\text { No of } \\
\text { samples }\end{array}$ & $\begin{array}{l}\text { Cement } \\
(\mathbf{k g})\end{array}$ & $\begin{array}{l}\text { Fine } \\
\text { aggregate (kg) }\end{array}$ & $\begin{array}{l}\text { Coarse } \\
\text { aggregate (kg) }\end{array}$ & $\begin{array}{l}\text { Fiber } \\
\text { content (kg) }\end{array}$ & $\begin{array}{l}\text { Water } \\
\text { (Ltrs) }\end{array}$ \\
\hline Control concrete & 6 & 22.32 & 39.84 & 67.2 & 0 & 10.2 \\
\hline $\begin{array}{l}\text { Mix with 0.5\%of fiber } \\
\text { by total weight }\end{array}$ & 6 & 22.32 & 39.84 & 67.2 & 0.1116 & 10.2 \\
\hline $\begin{array}{l}\text { Mix with 1\%of fiber by } \\
\text { total weight }\end{array}$ & 6 & 22.32 & 39.84 & 67.2 & 0.2232 & 10.2 \\
\hline $\begin{array}{l}\text { Mix with 1.5\%of fiber } \\
\text { by total weight }\end{array}$ & 6 & 22.32 & 39.84 & 67.2 & 0.3348 & 10.2 \\
\hline $\begin{array}{l}\text { Mix with 2\%of fiber by } \\
\text { total weight }\end{array}$ & 6 & 22.32 & 39.84 & 67.2 & 0.4464 & 10.2 \\
\hline
\end{tabular}

Note: - that the fibers added were not used to replace cement or aggregates since the same principle as that used in reinforcing concrete with steel was followed. In steel reinforced concrete none of the composites, i.e. cement or aggregates, is replaced by steel.

\section{Size and type of sample used}

The Standard cast iron molds of size $15 \mathrm{~cm} \times 15 \mathrm{~cm} \times 15 \mathrm{~cm}$ were used in the preparation of concrete cubes for compressive strength test and $50 \mathrm{~cm} \times 10 \mathrm{~cm} \times 10 \mathrm{~cm}$ size beams for flexural strength test.

One sample had six cubes for each different percentage of fiber and the $0 \%$ was used as a control for the concrete compressive strength test. And for the flexural strength also one sample had six beams with different percentage of fiber, the $0 \%$ used as a control Samples were prepared for 7 and 28days of curing to know the early strength and final strength of concrete fiber. The total numbers of samples were 30 cubes and 30 beams.

\section{Fresh and Hardened Concrete Property Fresh Concrete Property Workability (slump test)}

Workability embodies certain characteristics of fresh concrete, such as consistency and cohesiveness. Slump test is the simplest test for workability and are most widely used on construction sites. The slump test is a qualitative test that measures the consistency of a cone of fresh concrete. The slumped concrete takes various shapes, and according to the profile of slumped concrete, the slump is termed as true slump, shear slump or collapses slump. If a shear or collapse slump is obtained, a fresh sample should be obtained and the test repeated. A collapse slump is an indication of too wet a mix. It generally means that the mix is too wet or is a high workability mix, for which slump test is not appropriate.

The mixed concrete was checked for workability by filling the standard slump cone with three layers by rodding each layer for 25 times. According to ASTMC143/C143M (2011) concretes having slumps less than $15 \mathrm{~mm}$ may not be adequately plastic and concretes having slumps greater than about $230 \mathrm{~mm}$ may not be adequately cohesive for this test to have significance. The slump test carried out for all six mixes of each $\%$ of fiber were done using the apparatus showed below.

Between each mix, the tools were cleaned using tap water to ensure that there was no contamination between the mixes. After checking the slump the mixed concrete was placed in the moulds and was well compacted in three layers with the help of a tape rode by rodding each layer with 25 times for the cylindrical moulds, as well as side compaction of the moulds was carried out by using tire hammer.

\section{Fresh concrete unit weight}

Density or unit weight properties of the fresh concrete was investigated by using mold with constant weight of $5.4 \mathrm{~kg}$ and volume of 9 litter or $0.009 \mathrm{~m} 3$. According to ACI318M (2011), fresh concrete properties can be determined by their respective maximum size of aggregates. The fresh concrete unit weight was calculated by using the following equation. 
Density $=(\mathrm{W} 2-\mathrm{W} 1) / \mathrm{V}$ Equation 3.1

Where:-

$\mathrm{W} 1=$ Weight of mold that is constant $5.4 \mathrm{Kg}$

$\mathrm{W} 2=$ Weight of mold plus weight of fresh concrete in $\mathrm{Kg}$

$\mathrm{V}=$ Volume of mold in M3

\section{Hardened Concrete Property}

Hardened concrete properties were tested on C-25 grade concrete specimens, with and without sheep wool as fiber reinforcement. The percentage of sheep wool fiber was varying from $0 \%$ to $2 \%$ with an increase of $0.5 \%$ iteration. During the casting of test samples, it was observed that mixing of sheep wool in the concrete to achieve homogeneity is a problem at concentration above $1.5 \%$ of human hair, resulting in balling and lumping of wool fibers which will ultimately affect the mechanical properties of the concrete. Because if the fibers are not properly mix with the concrete it's impossible to gaining the required strength it may collect in one place abundantly and in other side it may be there is no fiber so, lacking of uniform distribution definitely affect the strength of concrete.

\section{Unit weight determination}

The unit weight of hardened concrete determined by taking density of concrete casted in cylinders moulds. As the study use sheep wool as a fiber in different percentages so, determining each unit weight of different percentages of fibered concrete helps to know the density variation of concrete of differ by fiber percentage and to analyze the exact purpose of this type of concrete. Unit weight is gain by dividing the weight of sample at the age of 28 by the volume of sample.

\section{Compression Test}

Compressive strength test of concrete is the most common test of hardened concrete. Also many codes and design manuals are prepared based on this property and many other properties of concrete depend on the compressive strength of concrete. The compressive strengths of concrete specimens in this study were determined after 7 and 28 days of curing by testing the cubes in a calibrated compression machine with a rate of loading of $5 \mathrm{~N} / \mathrm{mm} 2$ per second. For each of the mixes the mean values of three cubes were taken as their compressive strength. The strength reductions by varying the fiber percentage of concrete were calculated by the following equation.

It was moulded in cast-iron separable moulds, which were oiled previous to placing the concrete. The concrete was deposited in layers approximately 3 inches thick, and each layer was tamped weighing $13 \mathrm{f}$ pounds, for 25 times per each layer. In moulding the cubes an effort was made to "spade" back the concrete from the sides of the mould, as was done in moulding the beams. $150 \times 150 \times 150 \mathrm{~mm}$ size of cube was used. During the placing of concrete in the moulds after tamping the last layer hit the mould with rubber axe to compact until the specified conditions were attained and finish the surface with trowel. Then marked and dated casted concrete specimens. After 24 hours the specimens were removed from the moulds and immediately submerged in water for curing in the dark room. After 7 and 28 days the specimens were tested using the cube crushing test.

For determining the effect of hair as fiber in concrete following tests were performed: strength are two essential qualities in concrete, in order that a structure may be put to the use for which it is intended as soon as possible and that there shall be no subsequent deterioration in strength. The least age at which any tests were made was four weeks, and at that period in no case except that of the cinder concrete, wet consistency, did the compressive strength fall below 2,000 pounds per square inch, while the cinder concrete had in every case a compressive strength of at least 1,000 pounds per square inch.

The test was carried out in the following steps: The specimens were tested by compression testing machine after 7 days and 28 days of curing. They were removed from water and excess water wiped off. They were then placed on the bearing surface of the compression machine with the smooth surface facing the front. A uniform rate of loading was applied till the failure of the cube. The maximum load was noted and the compressive strength was calculated.

\section{Apparatus}

Compression testing machine

\section{Flexural Strength test}

Flexural properties are evaluated according to ASTM D790. For this study use CONTROL universal flexural testing machine of model c0820/c with $2000 \mathrm{kn}$ maximum capacity force, $31415.9 \mathrm{~mm} 2 \mathrm{ram}$ area du piston, $900 \mathrm{~mm}$ ram stroke course du piston, $3000 \mathrm{~kg}$ weight machine, $5000 \mathrm{~W}$ power, $330 \mathrm{~V}$ voltage and hydraulic oil of ISO VG $32+68$ a cross head speed of $1.3 \mathrm{~mm} / \mathrm{min}$. the dimension of the specimen were $127 \mathrm{~mm}$ in length, $12.7 \mathrm{~mm}$ in width and $3 \mathrm{~mm}$ thickness (Standard A. D).

The beam moulds consisted of three long steel channels with flanges turned outward, forming the sides and bottom of the mould. The ends were closed by short pieces of channels. The side and end pieces were removable. The moulds were oiled before the concrete was placed, to prevent adhesion to the surface of the steel. In moulding the plain beams the concrete was 
deposited in three layers of about equal thickness. The tamping was done by hand with a 13f-pound tamper having a rectangular head $1 \mathrm{~J}$ by $3 £$ inches. The tamping was started at one side of one end of the mould and the tamper moved toward the opposite side, the width of the tamper at each stroke. The tamper was then set forward and the process repeated. In this way each part of the layer was tamped once. The mould was gone over twice in this way, after which the concrete was spaded back from the sides of the mould and the layer tamped a third time. The same operation was followed for each of the three layers, 40 strikes for each layer in the case of beam because its surface area increases than cubes. After tamping the last layer hit the mould with rubber axe to compact until the specified conditions were attained. The surface of each beam was finished as smooth as possible by troweling. The side and end pieces of the mould were removed at the end of twentyfour hours, and the beams were placed on water tub for $7 \& 28$ days for curing. $100 \times 50 \times 500 \mathrm{~mm}$ size of mould was used with $0,0.511 .5 \& 2 \%$ fiber for 7 and 28 days of curing then the specimens were tested onepoint bending test machine.

\section{Apparatus}

Flexural testing machine

Split tensile strength test

This test result of split tensile was gain from by using formula that drives result of compressive strength test to split tensile according to EBCS 2 (EBCS, 2014).

$F c k=0.8 f c u$ equation 3.2

Where $f c t m=0.3 f c k^{2 / 3}$

\section{Method of Mixing}

All concrete was mixed in a mixer, which is equipped with a charging hopper. All concrete was mixed two minutes dry and three minutes wet, after which it was dumped on the cement floor, shoveled into wheelbarrows and wheeled to the molding floor. A sufficient tool was charged into the mixer to make concrete. The laboratory batching mixer concrete is used.

\section{CHAPTER FOUR}

\section{RESULTS AND DISCUSSION \\ Concrete Ingredients Test Result \\ Fine aggregate}

Table-4.1: Sieve analysis results of fine aggregate

\begin{tabular}{|c|c|c|c|c|c|c|c|c|}
\hline \multirow{2}{*}{$\begin{array}{l}\text { ASTM sieve } \\
\text { designation }\end{array}$} & \multirow{2}{*}{$\begin{array}{l}\text { Sieve } \\
\text { size } \\
(\mathrm{mm})\end{array}$} & \multicolumn{3}{|c|}{ Weight retained (gm.) } & \multirow{2}{*}{$\begin{array}{l}\text { Total } \\
\text { weight } \\
\text { retaine } \\
\text { d }\end{array}$} & \multirow{2}{*}{$\begin{array}{l}\text { Cumulativ } \\
\text { e retained } \\
(\%)\end{array}$} & \multirow{2}{*}{$\begin{array}{l}\text { Cumulative } \\
\text { passing }(\%)\end{array}$} & \multirow{2}{*}{$\begin{array}{l}\text { Specification } \\
\% \text { passing } \\
\text { (ESC.D3.20) }\end{array}$} \\
\hline & & $\begin{array}{l}\text { Sampl } \\
\text { e } 1\end{array}$ & $\begin{array}{l}\text { Sampl } \\
\text { e } 2\end{array}$ & $\begin{array}{l}\text { Sample } \\
3\end{array}$ & & & & \\
\hline $3 / 8$ & 9.50 & 0 & 0 & 0 & 0 & 0 & 100 & 100 \\
\hline No.4 & 4.75 & 65 & 55 & 60 & 60 & 3 & 97 & $95-100$ \\
\hline No.8 & 2.36 & 225 & 205 & 220 & 216.67 & 10.75 & 87.25 & $80-100$ \\
\hline No.16 & 1.18 & 345 & 310 & 325 & 326.67 & 16.375 & 30.135 & $50-85$ \\
\hline No.30 & 600 & 745 & 760 & 750 & 751.67 & 37.625 & 32.25 & $25-60$ \\
\hline No.50 & 300 & 470 & 495 & 480 & 481.67 & 24.125 & 8.29 & $5-30$ \\
\hline No.100 & 150 & 130 & 150 & 140 & 140 & 7.00 & 1.23 & $0-10$ \\
\hline Pan & & 20 & 25 & 30 & 25 & 1.13 & 0 & \\
\hline SUM & & 2000 & 2000 & 2000 & & 100 & 305.2 & \\
\hline
\end{tabular}

$\mathrm{FM}=\frac{\sum \text { Commulative Retained } \%}{100}$ .equation 4.1

Fineness modulus $=\frac{305.2}{100}=3.05$ 


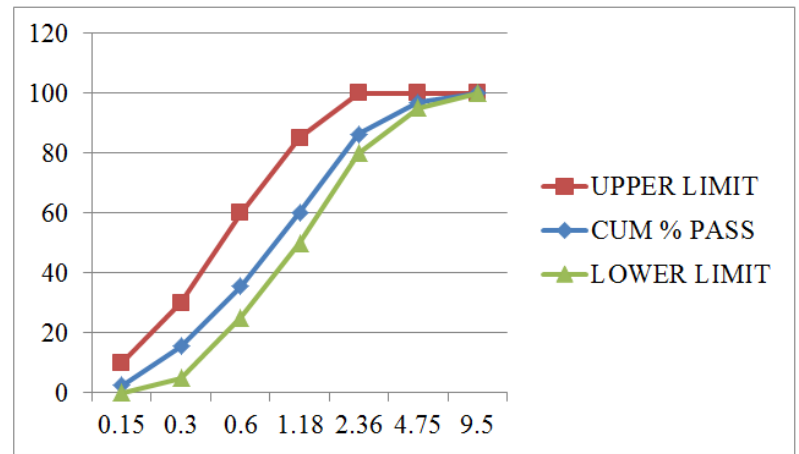

Fig-4.1: gradation of fine aggregate

\section{Water absorption and specific gravity}

The fine aggregate water absorption and specific gravity general calculation and sampling is indicated on Appendix. But the result gained designate bellow.

Table-4.2: Fine aggregate results of water absorption and specific gravity

\begin{tabular}{|l|l|l|}
\hline No & Test conducts & Result \\
\hline 1 & Bulk specific gravity (SSD basis) & 2.47 \\
\hline 2 & Apparent specific gravity & 2.55 \\
\hline 3 & Water absorption, dry weight & 1.53 \\
\hline
\end{tabular}

From ASTMC33/C33M [25], absorption capacity ranges from 0.2 to $2 \%$ for fine aggregates. As a result, the fine aggregate is in range of the limitation of ASTM.

\section{Unit weight}

The stroked bulk density of aggregates used for normal weight concrete generally ranges from 1200 to $1760 \mathrm{~kg} / \mathrm{m} 3$ [29]. The average unit weight of the fine aggregate samples results of loss and compacted unit weight was 1565 and $1726 \mathrm{~kg} / \mathrm{m} 3$ respectively that is near in the range. Detail result discus on Appendix.

\section{Moisture content}

The result of moisture content calculated as:

Percentage of moisture content $=\frac{500-490}{490} \times 100=2 \%$

Silt content

Ethiopian standard for silt content restricts the silt content exceed $6 \%$ and the organic impurity limit is $1-3$. If it exceeds this maximum values, the standard recommends washing or rejecting the sand. But in this study the result gained was in the allowable range that was $4.2 \%$ and also the organic impurity laid on sieve no.1.

General properties of fine aggregate gain from laboratory test indicate on the next table

\section{Coarse aggregate}

\section{Gradation}

Table-4.3: Sieve analysis of coarse aggregate results

\begin{tabular}{|c|c|c|c|c|c|c|c|c|}
\hline \multirow{2}{*}{$\begin{array}{l}\text { ASTM sieve } \\
\text { designation }\end{array}$} & \multirow{2}{*}{$\begin{array}{l}\text { Sieve } \\
\text { size } \\
(\mathbf{m m})\end{array}$} & \multicolumn{3}{|c|}{ Weight retained (gm.) } & \multirow{2}{*}{$\begin{array}{l}\text { Retained } \\
(\%)\end{array}$} & \multirow{2}{*}{$\begin{array}{l}\text { Cumulative } \\
\text { retained (\%) }\end{array}$} & \multirow{2}{*}{$\begin{array}{l}\text { Cumulative } \\
\text { passing }(\%)\end{array}$} & \multirow{2}{*}{$\begin{array}{l}\text { Specification } \\
\text { \% passing } \\
\text { (ESC.D3.20) }\end{array}$} \\
\hline & & $\begin{array}{l}\text { Sample } \\
1\end{array}$ & $\begin{array}{l}\text { Sample } \\
2\end{array}$ & $\begin{array}{l}\text { Sample } \\
\mathbf{3}\end{array}$ & & & & \\
\hline 3 & 75 & - & - & - & & - & & - \\
\hline 2 & 50 & - & - & - & - & & & - \\
\hline $11 / 2$ & 37.5 & 0 & 0 & 0 & 0 & 0 & 100 & 100 \\
\hline 1 & 25 & 510 & 520 & 515 & 515 & 10.30 & 89.70 & $90-100$ \\
\hline $33 / 4$ & 19 & 2080 & 2260 & 2170 & 2170 & 43.40 & 46.30 & $40-85$ \\
\hline $1 / 2$ & 12.5 & 1780 & 1575 & 1677.5 & 1677.5 & 33.55 & 12.75 & $10-50$ \\
\hline $3 / 8$ & 9.5 & 455 & 465 & 460 & 460 & 9.20 & 3.55 & $0-15$ \\
\hline No.4 & 4.75 & 165 & 175 & 170 & 170 & 3.40 & 0.15 & $0-5$ \\
\hline Pan & & 10 & 5 & 7.5 & 7.5 & 0.15 & 600 & \\
\hline SUM & 5000 & 5000 & 5000 & 5000 & 5000 & 100 & 749.3 & \\
\hline
\end{tabular}

Fineness modulus of coarse aggregate, $F M=\frac{749.3}{100}=7.49$ 


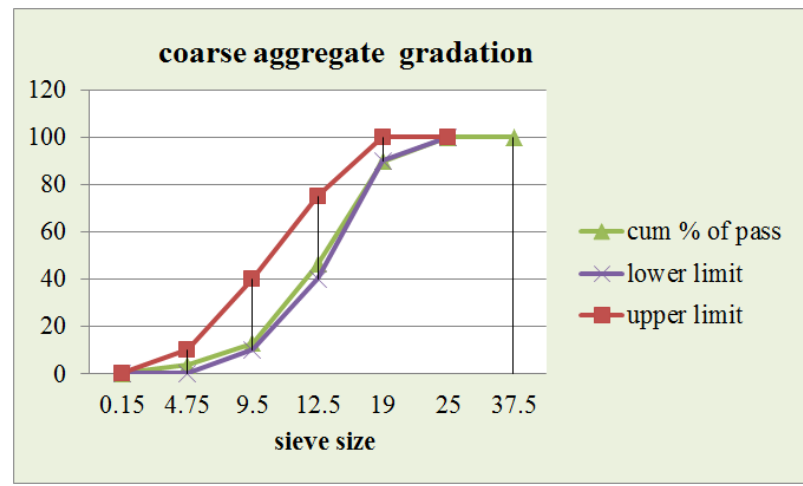

Fig-4.2: Coarse aggregate gradation result

\section{Water absorption and specific gravity}

Table-4.4: Coarse aggregate water absorption and specific gravity test results

\begin{tabular}{|l|l|l|}
\hline No & Test conducts & Result \\
\hline 1 & Bulk specific gravity (SSD basis) & 2.69 \\
\hline 2 & Apparent specific gravity & 2.75 \\
\hline 3 & Water absorption, dry weight & 1.26 \\
\hline
\end{tabular}

Generally, according to ASTMC33/C33M (2011) the limitation for bulk specific gravity (SSD) is from 2.4 to 3.0 and absorption capacity ranges from 0.2 $\%$ to $4 \%$, for coarse aggregates. Accordingly, the aggregates are within ASTM limit.

\section{Unit weight}

The average unit weight of the coarse aggregate samples of loss and compacted unit weight was 1456 and $1726 \mathrm{~kg} / \mathrm{m} 3$ respectively that was in the range of ACI standard.

\section{Moisture content}

The result gain from this test was:-

- Weight of original sample $=2000 \mathrm{gm}$.

- Weight of oven-dry sample= $1985 \mathrm{gm}$.

$\%$ of moisture content $=\frac{2000-1985}{1985} \times 100=0.76 \%$

\section{RESULTS AND DISCUSSION ON FRESH AND HARDEN CONCRETE PROPERTIES}

\section{Fresh Concrete Property}

Test result on workability of fresh concrete
The addition of fiber reduced the workability of the fresh concrete. This is attributed to the fact that the fibers absorb some of the water in the concrete mix making the mix be of less flow. But sheep wool absorbs the least water from the mix. Probably, this is attributed to the plasticity of sheep wool which makes the wool absorbs very little water.

As a result, since the slump of the study found in the range of 20-35 mm, sheep wool fibered concrete is good in plastic and cohesive properties. As a result it was found that sheep wool fibered concrete will be good to minimize segregation of fresh concrete during placing and consolidation.

Table-4.5: Fresh concrete slump test results

\begin{tabular}{|l|l|l|}
\hline Fiber type & $\begin{array}{l}\text { Fiber } \\
\text { content }(\%)\end{array}$ & $\begin{array}{l}\text { Slump } \\
\text { result }\end{array}$ \\
\hline \multirow{4}{*}{$\begin{array}{l}\text { Sheep wm) } \\
\text { fiber }\end{array}$} & 0 & 35 \\
\cline { 2 - 3 } & 0.5 & 33 \\
\cline { 2 - 3 } & 1.0 & 30 \\
\cline { 2 - 3 } & 1.5 & 28 \\
\cline { 2 - 3 } & 2 & 20 \\
\hline
\end{tabular}

From the experiment it was realized that there was a variation on the consistency and workability of the concrete mix depending on the fiber percentage used in the mix. The slumps of the concrete containing sheep wool have shown reduction as the fiber content increases.

But the slump result record different result for different percentage of fiber used, for $0.5 \%$ it decrease by $5.26 \%$ from the control, for $1 \%$ fiber used there is also a declination of slump from control by $13.15 \%$, for $1.5 \%$ it a declination by $20 \%$ and for the $2 \%$ fiber used $42.85 \%$ also it declination slump was recorded. From this it's easy to understand as the fiber percentage increase the slump or workability decrease concurrently. Due to the formation of balling and void even at proper compactions.

\section{Fresh concrete unit weight result}

Fresh concrete properties can be determined by their respective maximum size of aggregates as a result for the $20 \mathrm{~mm}$ size of coarse aggregates the corresponding unit weight found was $1700 \mathrm{~kg} / \mathrm{m} 3$. The fresh concrete density decreases as percentage of fiber increases.

Table-4.6: Fresh concrete density

\begin{tabular}{|l|c|l|}
\hline Fiber in \% & Weight of fresh concrete plus mold $\mathbf{( K g )}$ & Density of fresh concrete $\left(\mathbf{K g}_{\mathbf{M}} \mathbf{M}^{\mathbf{3}}\right)$ \\
\hline 0 & 27.7 & 2480 \\
\hline 0.5 & 27.2 & 2435 \\
\hline 1.0 & 27 & 2417 \\
\hline 1.5 & 26.2 & 2345 \\
\hline 2 & 25.5 & 2283 \\
\hline
\end{tabular}


The result shows that as the fiber concrete increase the fresh concrete density reduce by different percentage as stated in the above table. As shown in the above table when $0.5 \%$ of sheep wool fiber added the density of concrete reduces by $1.8 \%$ and the reduction continued to $7.9 \%$ till using $2 \%$ of the sheep wool fiber used. Whereas $2.5 \%$ and $5.4 \%$ reductions were observed for 1and $1.5 \%$ sheep wool fiber used concrete respectively.

\section{RESULTS AND DISCUSSION ON HARDEN CONCRETE PROPERTIES \\ Unit weight of hardened concrete}

The weights and the dimension of the concrete cubes were measured before testing the moulds compressive and split tensile strength. Unit weights of the concrete were calculated by using the 28 days average unit weight as shown on the following table

Table-4.7: Unit weights of different fiber \% concrete cubes

\begin{tabular}{|l|l|l|}
\hline Sample & Sheep wool \% & Density $\left(\mathbf{k g} / \mathbf{m}^{\mathbf{3}}\right)$ \\
\hline 1 & 0 & 2477 \\
\hline 2 & 0.5 & 2445 \\
\hline 3 & 1.0 & 2429 \\
\hline 4 & 1.5 & 2411 \\
\hline 5 & 2.0 & 2398 \\
\hline
\end{tabular}

The unit weight values used for the analysis of this section were measured from the concrete cubes sample after 28 days of curing. From the results, it was found that there were significant reductions of unit weight while percentages of sheep wool increases. As shown in the above table $0.5 \%$ of sheep wool added the densities of concrete reduce by $1.3 \%$ and the reduction continued to $3.16 \%$ till using $2 \%$ of the sheep wool. Whereas a $1.9 \%$ and $2.63 \%$ reduction was observed with, $1 \%$ and $2 \%$ sheep wool fibered concrete respectively.

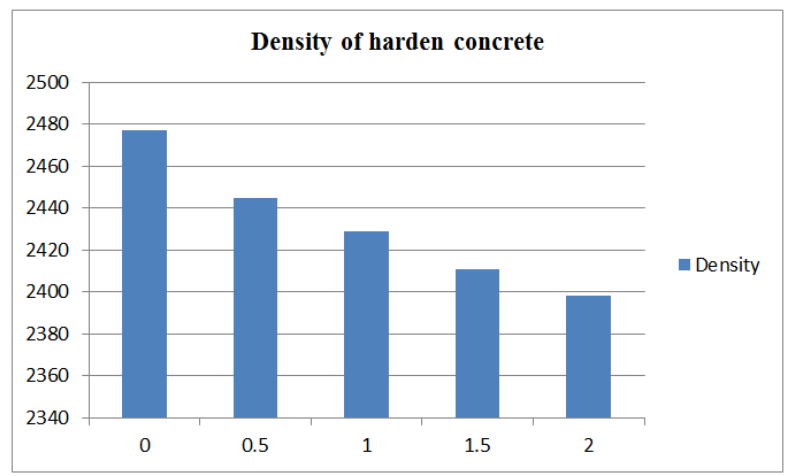

Fig-4.3: Densities of fibered concrete cubes
Using concrete with a lower density can result in significant benefits in terms of load bearing elements of smaller cross-section and a corresponding reduction in the size of foundations. Occasionally, the use of concrete with a lower density permits construction on ground with a low load-bearing capacity. Furthermore, with lighter concrete, the formwork need withstand a lower pressure than would be in case with normal weight concrete, and also the total mass of materials to be handled is reduced with a consequent increase in productivity [30]. Therefore, all the above mentioned low density concrete benefits can be achieved using sheep wool fiber concrete.

Table-4.8 Unit weights of different \% of fibered concrete beams

\begin{tabular}{|r|r|r|}
\hline Sample & Replaced OPC (\%) & Density (kg/m3) \\
\hline 1 & 0 & 2477 \\
\hline 2 & 0.5 & 2445 \\
\hline 3 & 1 & 2429 \\
\hline 4 & 1.5 & 2411 \\
\hline 5 & 2 & 2398 \\
\hline
\end{tabular}

The unit weight values of concrete beams samples after 28 days of curing was shown a significant reduction of unit weight when comparing with the control while the percentages of fiber decrease. Using concrete with a lower density can result in significant benefits in terms of load bearing elements of smaller cross-section and a corresponding reduction in the size of foundations. Occasionally, the use of concrete with a lower density permits construction on ground with a low load-bearing capacity. Furthermore, with lighter concrete, the formwork need withstand a lower pressure than would be in case with normal weight concrete, and also the total mass of materials to be handled is reduced with a consequent increase in productivity [31]. Therefore, the reduced density of concrete containing sheep wool as fiber can provide with all the benefits mentioned which are associated with a lower density. Therefore, using this fibered concrete is advantageous for normal weight concrete structures.

\section{Compressive strength test}

Compressive strength test of samples was done at the age of 7 and 28 . The 7 th age results indicate on the following table. By converting the of cylinder to compressive

Table-4.9: The 7th day's Average compressive strength values of concrete cubes

\begin{tabular}{|l|c|c|c|}
\hline No & Fiber \% & Average Maximum load(ton) & Compressive stress (MPa) \\
\hline Control & 0 & 50.5 & 22.0 \\
\hline \multirow{4}{*}{ Sheep wool fiber } & 0.5 & 50.6 & 22.12 \\
\cline { 2 - 4 } & 1.0 & 53.5 & 23.05 \\
\cline { 2 - 4 } & 1.5 & 54.2 & 25.01 \\
\cline { 2 - 4 } & 2.0 & 53.6 & 23.54 \\
\hline
\end{tabular}


The sheep wool fiber concrete at the age of 7 days result show that addition of this fiber resulted in rise of concrete compressive strength compared with the control mix, sheep wool fiber of $0 \%$. As the fiber percentages increases the corresponding compressive strength increase to some extent and again reduce as the fiber percentage increase in excess. From $0.5 \%$ to $1.5 \%$ shows continuous increase in compressive strength but in the $2 \%$ addition of fiber there was a reduction in compressive strength when compare with $1.5 \%$ of fiber used. This shows that increasing the fiber percentage beyond this, resulted with reduction of compressive strength of fibered concrete.

The probable reason for decreasing of fibered concrete compressive strength is due to the high amount addition sheep wool as a fiber. In addition to this, the high content of sheep wool was resulted also low workability.

Table-4.10: The 28days compression test and the corresponding compressive stress

\begin{tabular}{|r|c|c|c|}
\hline No & Fiber \% & Average Maximum load(ton) & Compressive stress (MPa) \\
\hline Control & 0 & 67.2 & 33 \\
\hline Sheep wool fiber & 0.5 & 67.9 & 33.19 \\
\cline { 2 - 4 } & 1.0 & 77.3 & 34.8 \\
\cline { 2 - 4 } & 1.5 & 77.4 & 35.54 \\
\cline { 2 - 4 } & 2.0 & 47.7 & 25.7 \\
\hline
\end{tabular}

The results of sheep wool fibered concrete at the age of 28 days was shown the same result of increasing for $0.5,1$ and $1.5 \%$ and reduce the result at $2 \%$ of sheep wool fibered concrete. But all percentages of fibers used were rise of concrete compressive strength compared with the control mix, $0 \%$ sheep wool fiber. Thee fibered concrete increase the compressive strength as the date of curing increase because concrete hydration reaction is not finished in a few days. The sheep wool fibered concrete compressive strength result at the age of 28 days, shown in the next figure.

When comparing the result of compressive strength of sheep wool fiber concrete at the age of 7 and 28 , the 28 days of concrete strength was better than the 7 th days this is due to concrete gain $99 \%$ of its compressive strength at the age of 28 based on this, the study use the 28 day split tensile strength test result to make suggestions.

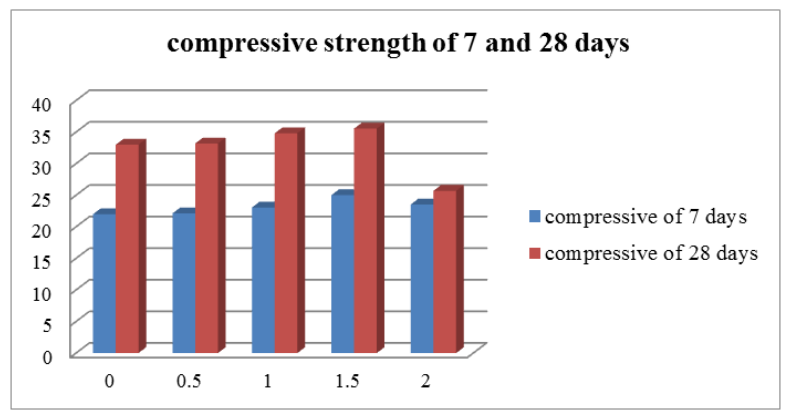

Fig-4.4: Compressive strength of 7 and 28 days

\section{Flexural/Bending Strength Test Result}

The results of the three point loading tests on beam specimens are shown below, with $0.5,1,1.5 \&$ $2 \%$ addition of sheep wool as a fiber.

Table-4 .12: Sheep wool fibered concrete flexural strength at the age of 7

\begin{tabular}{|c|c|c|c|c|c|c|c|c|c|}
\hline \multirow{2}{*}{$\begin{array}{r}\begin{array}{r}\text { Fiber } \\
\text { percen } \\
\text { tage }\end{array} \\
0\end{array}$} & \multirow{2}{*}{$\begin{array}{r}\begin{array}{c}\text { Aspect } \\
\text { ratio }\end{array} \\
-\end{array}$} & \multicolumn{3}{|c|}{ Total load tons $(\mathrm{KN})$} & \multirow{2}{*}{$\begin{array}{r}\text { Average } \\
\begin{array}{r}\text { maximum load } \\
\text { resistance }(\mathbf{K N})\end{array} \\
27.3\end{array}$} & \multicolumn{3}{|c|}{ Flexural load (MPa) } & \multirow{2}{*}{$\begin{array}{r}\begin{array}{r}\text { Average } \\
\text { flexural load } \\
\text { (MPa) }\end{array} \\
3.68 \\
\end{array}$} \\
\hline & & 27.1 & 27.5 & 27.3 & & 3.66 & 3.71 & 3.69 & \\
\hline 0.5 & $20-39$ & 28.5 & 28.6 & 28.7 & 28.6 & 3.85 & 3.86 & 3.87 & 3.86 \\
\hline 1.0 & $20-39$ & 29.9 & 30 & 29.8 & 29.9 & 4.04 & 4.05 & 4.02 & 4.04 \\
\hline 1.5 & $20-39$ & 30.1 & 30.8 & 30.6 & 30.5 & 4.06 & 4.16 & 4.13 & 4.12 \\
\hline 2.0 & $20-39$ & 29.4 & 29.6 & 29.5 & 29.5 & 3.97 & 3.99 & 3.98 & 3.98 \\
\hline
\end{tabular}

This table shows the 7 th day flexural strength of fibered concrete. For the $0.5,1$ and $1.5 \%$ of fiber addition shows strength rise continuously but at $2 \%$ of sheep wool fiber used, the rise of strength reduce to some extent when compare with the previous percentage. Strength reduction of the $2 \%$ sheep wool fiber concrete is due to excess increasing of fiber percentage. Due to excess addition of fiber cause balling in mixing this prevent proper mixing so as a result reduce strength of concrete. 
Table-4.13: Sheep wool fiber concrete Flexural Strength at 28 days

\begin{tabular}{|l|l|l|l|l|l|l|l|l|l|}
\hline $\begin{array}{l}\text { Fiber } \\
\text { percentage }\end{array}$ & $\begin{array}{l}\text { Aspect } \\
\text { ratio }\end{array}$ & \multicolumn{2}{l}{$\begin{array}{l}\text { Maximum flexural } \\
\text { load resistance(KN) }\end{array}$} & $\begin{array}{l}\text { Average } \\
\text { maximum load } \\
\text { resistance(KN) }\end{array}$ & \multicolumn{2}{l|}{ Flexural load (MPa) } & $\begin{array}{l}\text { Average } \\
\text { flexural load } \\
\text { (MPa) }\end{array}$ \\
\hline 0 & - & 27.4 & 27.7 & 27.7 & 27.6 & 3.7 & 3.74 & 3.74 & 3.73 \\
\hline 0.5 & $20-39$ & 29.6 & 30.4 & 33.3 & 31.1 & 4.0 & 4.1 & 4.5 & 4.2 \\
\hline 1.0 & $20-39$ & 31.0 & 31.5 & 31.4 & 31.3 & 4.19 & 4.25 & 4.24 & 4.22 \\
\hline 1.5 & $20-39$ & 34.8 & 34.5 & 34.6 & 34.63 & 4.7 & 4.66 & 4.67 & 4.68 \\
\hline 2.0 & $20-39$ & 29.1 & 29.5 & 29.6 & 29.4 & 3.93 & 3.98 & 3.99 & 3.97 \\
\hline
\end{tabular}

This table shows the 28th day flexural strength of fibered concrete. For the first 0.5, 1and 1.5\% addition of sheep wool fiber was resulted increasing of flexural strength. And for the $2 \%$ the flexural strength increase when compare with the control but the increasing rate reduce when compare the other percentages this is due to that excess increasing of fiber reduce the flexural strength of fibered concrete. Since the excess addition of fiber cause balling in mixing this prevent proper mixing so as a result reduce strength of concrete.

Addition of fiber to $1.5 \%$ had a good result for both after 7days of curing as well as at 28days of curing. On increasing $\%$ addition of sheep wool to the concrete the compressive \& flexural strength goes on increasing and optimum strength was achieved when $1.5 \%$ sheep wool fiber was used.
When compare the flexural strength result of sheep wool fibered concrete with related literatures, some literatures had a good result at $1.5 \%$ replacement and some others at $2 \%$. In this study the researcher find good result at $1.5 \%$.

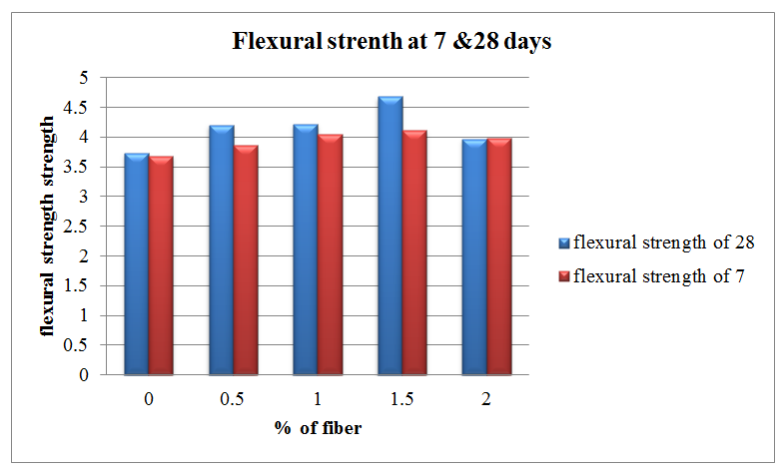

Fig-4.5: flexural strength at 7 and 28 days

\section{Split tensile strength}

Table-4.14: The 7th day's Average compressive strength values of concrete summery

\begin{tabular}{|l|c|c|c|}
\hline Fiber & Fiber content \% & Average Maximum load(ton) & Compressive stress (Mpa) \\
\hline Control & 0 & 50.5 & 22.0 \\
\hline \multirow{3}{*}{ Sheep wool } & 0.5 & 53.7 & 22.12 \\
\cline { 2 - 4 } & 1 & 53.9 & 23.05 \\
\cline { 2 - 4 } & 1.5 & 55.7 & 25.01 \\
\cline { 2 - 4 } & 2 & 53.7 & 23.54 \\
\hline
\end{tabular}

To convert the data gained from compressive strength test to split tensile follow the procedure put in EBCS 2 chapter 2.
Based on table 2.2 convert the compressive strength result gained from this study to cylindered $(150 \mathrm{~mm}$ diameter $300 \mathrm{~mm}$ height $)$ of size by multiplying with conversion factor of 1.25 .

Table-4.15: Converting the 7th day compression test results on cube to cylinder

\begin{tabular}{|l|l|l|l|l|}
\hline Fiber & Fiber content \% & Compressive stress (Mpa) & Conversion factor & Cylinders compression strength \\
\hline Control & 0 & 22.0 & 0.8 & 17.6 \\
\hline \multirow{3}{*}{ Sheep wool } & 0.5 & 23.4 & 0.8 & 18.72 \\
\cline { 2 - 5 } & 1 & 23.5 & 0.8 & 18.8 \\
\cline { 2 - 5 } & 1.5 & 24.0 & 0.8 & 19.2 \\
\cline { 2 - 5 } & 2 & 23.4 & 0.8 & 18.72 \\
\hline
\end{tabular}

Then based on this result convert to tensile strength by using equation 2.1 of EBCS

$\boldsymbol{F c k}=\mathbf{0 . 8} \boldsymbol{f c u}$ equation 4.1

Where $f c t m=0.3 f c k$ 
Table-4.16: Converting the 7th day cylinder compressive strength to tensile strength

\begin{tabular}{|l|l|l|l|}
\hline Fiber & $\begin{array}{l}\text { Fiber content } \\
\text { \% }\end{array}$ & $\begin{array}{l}\text { Cylinders compression } \\
\text { strength }\end{array}$ & $\begin{array}{l}\text { Tensile strength of } \\
\text { concrete cylinder Mpa }\end{array}$ \\
\hline Control & 0 & 17.6 & 1.98 \\
\hline \multirow{5}{*}{ Sheep wool } & 0.5 & 18.72 & 2.11 \\
\cline { 2 - 4 } & 1 & 18.8 & 2.12 \\
\cline { 2 - 4 } & 1.5 & 19.2 & 2.15 \\
\cline { 2 - 4 } & 2 & 18.72 & 2.11 \\
\hline
\end{tabular}
this study

Good result is gain at $1.5 \%$ of sheep wool fiber usage in this test same as others test conducted on concrete in

Table 4.17: Converting the 28th day compression test results on cube to cylinder

\begin{tabular}{|l|l|c|l|l|}
\hline Fiber & $\begin{array}{l}\text { Fiber content } \\
\text { \% }\end{array}$ & $\begin{array}{l}\text { Compressive stress } \\
\text { (Mpa) }\end{array}$ & $\begin{array}{l}\text { Conversion } \\
\text { factor }\end{array}$ & $\begin{array}{l}\text { Cylinders compression } \\
\text { strength }\end{array}$ \\
\hline Control & 0 & 33 & 0.8 & 26.4 \\
\hline \multirow{2}{*}{ Sheep } & 0.5 & 33.19 & 0.8 & 26.55 \\
\cline { 2 - 5 } wool & 1 & 34.8 & 0.8 & 27.84 \\
\cline { 2 - 5 } & 1.5 & 35.54 & 0.8 & 28.42 \\
\cline { 2 - 5 } & 2 & 25.7 & 0.8 & 20.56 \\
\hline
\end{tabular}

Then based on this result convert to tensile strength by using equation 2.1 of EBCS

$F c k=0.8 f c u$ ..equation 4.1

Where $f c t m=0.3 f c k$

\begin{tabular}{|l|c|c|c|}
\hline Fiber & $\begin{array}{l}\text { Fiber } \\
\text { content \% }\end{array}$ & $\begin{array}{l}\text { Cylinders compression } \\
\text { strength }\end{array}$ & $\begin{array}{l}\text { Tensile strength of concrete } \\
\text { cylinder Mpa }\end{array}$ \\
\hline Control & 0 & 26.4 & 2.65 \\
\hline \multirow{2}{*}{ Sheep } & 0.5 & 26.55 & 2.66 \\
\cline { 2 - 4 } wool & 1 & 27.84 & 2.74 \\
\cline { 2 - 4 } & 1.5 & 28.42 & 2.80 \\
\cline { 2 - 4 } & 2 & 20.56 & 2.25 \\
\hline
\end{tabular}

Here also a good result is gain at $1.5 \%$ sheep wool fiber usage in this test same as others test conducted on concrete in this study

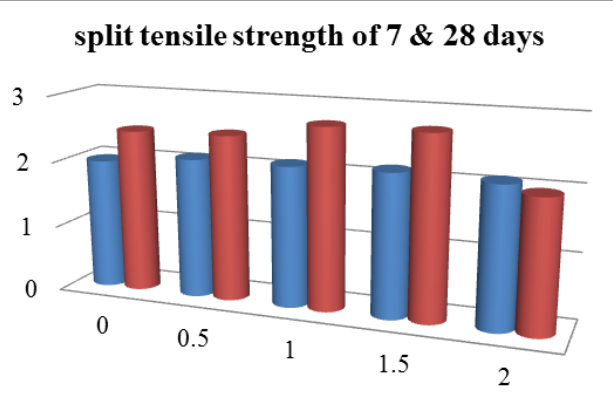

w split tensile strength of 7 split tensile strength of 28

Fig-4.6: Split tensile strength of $7 \& 28$ days

The variation of strength of concrete with an increase in fiber content $(\%)$

From the results shown that additional of fiber in plain concrete increases the strength of concrete up to a certain volume of fiber where further increase in fiber content causes a reduction in the strength of concrete. This fiber content, at which the maximum strength is reached, is called the optimum fiber content for this study it is $1.5 \%$.

It can be seen that with a longer period of curing i.e. 28days, the optimum fiber content can vary from that at 7 days. This can be explained by the various chemical reactions that undergo in the fiber-cement matrix and also the water absorption by the fibers. For instance the optimum fiber content at 28days was about $1.5 \%$. This shows that higher fiber content mixes have reduced strength as aging continues. Further $0.5 \%$ addition to the optimum amount leads to strength reduction this could be due to lack of proper binding between the fibers, especially where balling could have occurred during mixing. Also, as all water is used up during hydration, it leaves voids of the entrapped air reducing the strength of the concrete. It could also be an indication that the fiber deteriorates in the cementitious mix and more studies should be done to arrive at a suitable conclusion. 


\section{CHAPTER FIVE}

\section{CONCLUSION AND RECOMMENDATIONS Conclusion}

The use of sheep wool as a fiber in concrete production was studied and after the research work was completed, the following conclusions were made.

- The experiment concludes that there was a variation on the consistency and workability of the concrete mix depending on the fiber percentage used in the mix. The slumps of the concrete containing sheep wool have shown reduction as the fiber content increases. This is due to the formation of balling and void even at proper compactions.

- Mechanical properties of sheep wool fibered concrete such as split tensile strength, flexural strength and compression strength test with different percentage of sheep wool fiber range from 0 up to $1.5 \%$ are increase, maximum result maintained at $1.5 \%$. But at $2 \%$ usage of the fiber those strengths are become decrease.

- For the properties of sheep wool fibered concrete such as split tensile strength, flexural strength and compression strength test conducted the optimum amount was recorded at $1.5 \%$ of sheep wool fiber usage. At $1.5 \%$ of the fiber it can be enhances the properties of concrete particularly flexural and split tensile strength. The crack modes of sheep wool fibers are effective in crack resistance of concrete.

\section{RECOMMENDATION}

Having successfully undertaken the research, on effects of sheep wool fiber on properties C-25 concrete, while considering its necessity and advantages that it offers, it is in my opinion that it should be investigated more than this case. However, the following is my recommendation for stakeholders.

- Further studies should be taken on the behavior of the sheep wool fiber in the cementitious mix for a longer time period of more than 28 days. Since long term performance is one of the major limitations, durability must be properly assessed.

- To improve workability of the concrete chemical ad- mixture should be used. Since as percentage of fiber increase the mixes lose workability.

- Further study in reducing balling of fibers during mixing and also to increase workability should be undertaken in addition to the deterioration of the fibers after a prolonged life in the cementitious mix should be under study so as to increase durability.

- As well as good in the way of protecting environment from anxiety of increasing wastes, using sheep wool as a fiber in concrete production is recommended. The greater percentage for environmental pollution lies on non-decomposed matters like plastics, animal and human hair and other agricultural waste. Therefore, using those wastes from different area of agriculture in construction industries as a raw material reduce the effect on environment.

\section{APPENDIX 1 \\ MIX DESIGN PROCEDURES}

The mix design for C-25 non-air entrained normal strength concrete was done as per ACI 211.1. Mix design procedure manual.

Step-1: Choice of slump: consistent to the method of placement the slump was set to be $25-50 \mathrm{~mm}$ (minimum slump possible) is selected

Step-2: Maximum size of aggregate: Maximum size was fixed to be $20 \mathrm{~mm}$.

\section{Step 3: Target mean strength calculation}

From ACI 301 table 4.2.3.3C seen below for a 28-day compressive strength, when no test data is available.

\begin{tabular}{|l|c|}
\hline \multicolumn{1}{|c|}{$f_{c}^{\prime}, \mathrm{MPa}$} & $f_{c r}^{\prime}, \mathrm{MPa}$ \\
\hline Less than 21 & $f_{c}^{\prime}+7$ \\
\hline 21 to 35 & $f_{c}^{\prime}+8.3$ \\
\hline Over 35 & $1.1 f_{c}^{\prime}+5$ \\
\hline *When data are not available to establish standard deviation. \\
\hline
\end{tabular}

Step-4: Mixing water requirement: Based on the ACI table.3.8 seen below for the slump rang of 25$50 \mathrm{~mm}$ and a maximum size of $20 \mathrm{~mm}$ aggregates; the required mixing water is $180 \mathrm{~kg}$. Therefore, for the first trial mix the mixing water required was $180 \mathrm{~kg}$ of water. 


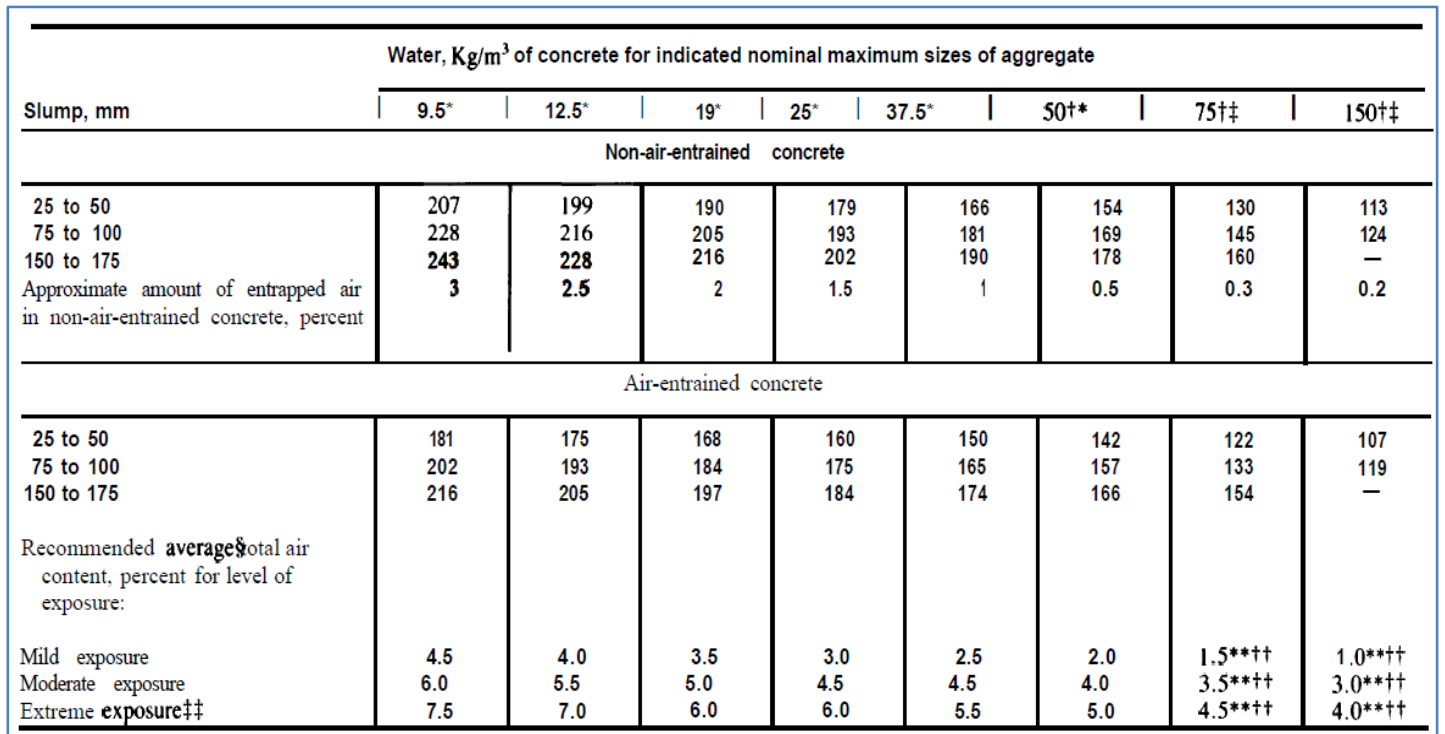

\section{Step 5: water to cement $(\mathrm{W} / \mathrm{C})$ ratio}

For $25 \mathrm{MPa}$ W/C ratio is 0.61 . From table 3.1 of ACI 211.1.81

\begin{tabular}{|c|c|c|c|}
\hline \multirow[b]{2}{*}{$\begin{array}{l}\text { Compressive strength } \\
\text { at } 28 \text { days, } \mathrm{MPa}^{*}\end{array}$} & \multicolumn{3}{|c|}{ Water-cement ratio, by mass } \\
\hline & $\begin{array}{c}\text { Non-air-entrained } \\
\text { concrete }\end{array}$ & I & $\begin{array}{l}\text { Air-entrained } \\
\text { concrete }\end{array}$ \\
\hline 40 & 0.42 & & - \\
\hline 35 & 0.47 & & 0.39 \\
\hline 30 & 0.54 & & 0.45 \\
\hline 25 & 0.61 & & 0.52 \\
\hline 20 & 0.69 & & 0.60 \\
\hline 15 & 0.79 & & 0.70 \\
\hline
\end{tabular}

Step-6: Determining Cement content: From this ratio the amount of cement required will be about 360KGs (180/0.61).

Step-7: Estimation of Coarse aggregate content: The dry mass of coarse-aggregate required for a cubic meter of concrete is equal to the value from ACI 211-Table 3.11 multiplied by the dry-rodded unit mass of the aggregate in kilograms per cubic meter. In sieve analysis, it was found that the fines modulus of fine aggregate was 3.05.The unit weight of the dry rodded coarse aggregates is $1585 \mathrm{KG} / \mathrm{m} 3$. From the table the percentage by volume of coarse aggregate with a nominal maximum size of $25 \mathrm{~mm}$ is about $67 \%$. This intern gives a mass of $1064.63(0.67 * 1585) \mathrm{Kg}$ of coarse aggregates.

\begin{tabular}{|c|c|c|c|c|}
\hline \multirow{2}{*}{$\begin{array}{c}\text { Nominal } \\
\text { maximum size } \\
\text { of aggregate, } \\
\mathrm{mm}\end{array}$} & \multicolumn{4}{|c|}{$\begin{array}{c}\text { Volume of dry-rodded coarse aggregate } \\
\text { per unit volume of concrete for different } \\
\text { fineness modulit of fine aggregate }\end{array}$} \\
\cline { 2 - 5 } & 2.40 & 2.60 & 2.80 & 3.00 \\
\hline 9.5 & 0.50 & 0.48 & 0.46 & 0.44 \\
12.5 & 0.59 & 0.57 & 0.55 & 0.53 \\
19 & 0.66 & 0.64 & 0.62 & 0.60 \\
25 & 0.71 & 0.69 & 0.67 & 0.65 \\
37.5 & 0.75 & 0.73 & 0.71 & 0.69 \\
50 & 0.78 & 0.76 & 0.74 & 0.72 \\
75 & 0.82 & 0.80 & 0.78 & 0.76 \\
150 & 0.87 & 0.85 & 0.83 & 0.81 \\
\hline
\end{tabular}




\begin{tabular}{|c|c|c|}
\hline \multirow{2}{*}{$\begin{array}{c}\text { Nominal } \\
\text { maximum size of } \\
\text { aggregate, mm }\end{array}$} & \begin{tabular}{c} 
First estimate of concrete unit mass, $\mathrm{kg} / \mathrm{m}^{3 *}$ \\
\cline { 2 - 3 }
\end{tabular} & $\begin{array}{c}\text { Non-air-entrained } \\
\text { concrete }\end{array}$ \\
\hline 9.5 & 2280 & $\begin{array}{c}\text { Air-entrained } \\
\text { concrete }\end{array}$ \\
12.5 & 2310 & 2200 \\
19 & 2345 & 2230 \\
25 & 2380 & 2275 \\
37.5 & 2410 & 2290 \\
50 & 2445 & 2350 \\
75 & 2490 & 2345 \\
150 & 2530 & 2405 \\
& & 2435 \\
\hline
\end{tabular}

Step-8: Fine aggregate content: it is clear that the estimated weight of the fresh Non air entrained concrete is $2375 \mathrm{KG}$. Deducting the weight of all the known ingredients gives the weight of the sand 770.37 Kg (2375-180-360-1064.63).

Step 9: Adjustments for moisture

\begin{tabular}{|c|c|c|c|c|c|}
\hline & Cement Kg/M3 & $\begin{array}{r}\text { Water } \\
\text { (Kg/M3or Lit/M3) }\end{array}$ & $\begin{array}{r}\text { Fine Aggregate } \\
(\mathrm{Kg} / \mathbf{M} 3)\end{array}$ & $\begin{array}{r}\text { Coarse Aggregate } \\
\text { (Kg/M3) }\end{array}$ & $\begin{array}{r}\text { Total } \\
\text { Kg/M3 }\end{array}$ \\
\hline Materials Per $\mathbf{M}^{3}$ & 360 & 180 & 770.37 & 1064.63 & 2375 \\
\hline Free moisture $\%$ & & - & - & 18.89 & 1.83 \\
\hline Absorption capacity & & - & 1.53 & 1.26 & 2.60 \\
\hline Adjustment & - & $111.21-8.20$ & +123.8 & $+19,48$ & 0 \\
\hline Adjusted per $\mathbf{M}^{3}$ & 360 & 86.98 & 779.17 & 1084.11 & 2330.09 \\
\hline Adjusted per $0.014 \mathrm{M}^{3}$ & 5.32 & 1.22 & 10.91 & 15.18 & 32.63 \\
\hline
\end{tabular}

\section{APPENDIX 2}

\section{MATERIAL TEST RESULTS}

Table-5.1: Sieve analysis of fine aggregate

\begin{tabular}{|c|c|c|c|c|c|c|c|c|}
\hline \multirow{2}{*}{$\begin{array}{l}\text { ASTM sieve } \\
\text { designation }\end{array}$} & \multirow{2}{*}{$\begin{array}{l}\text { Sieve } \\
\text { size } \\
(\mathbf{m m})\end{array}$} & \multicolumn{3}{|c|}{ Weight retained (gm.) } & \multirow{2}{*}{$\begin{array}{l}\text { Retaine } \\
\text { d (\%) }\end{array}$} & \multirow{2}{*}{$\begin{array}{l}\text { Cumulative } \\
\text { retained } \\
(\%)\end{array}$} & \multirow{2}{*}{$\begin{array}{l}\text { Cumulative } \\
\text { passing }(\%)\end{array}$} & \multirow{2}{*}{$\begin{array}{l}\text { Specification \% } \\
\text { passing } \\
\text { (ESC.D3.20) }\end{array}$} \\
\hline & & $\begin{array}{l}\text { Sample } \\
1\end{array}$ & $\begin{array}{l}\text { Sample } \\
2\end{array}$ & $\begin{array}{l}\text { Sample } \\
3\end{array}$ & & & & \\
\hline $3 / 8$ & 9.50 & 0 & 0 & 0 & 0 & 0 & 100 & 100 \\
\hline No.4 & 4.75 & 65 & 55 & 60 & 60 & 3 & 3 & $95-100$ \\
\hline No.8 & 2.36 & 225 & 205 & 220 & 216.67 & 10.75 & 13.75 & $80-100$ \\
\hline No.16 & 1.18 & 345 & 310 & 325 & 326.67 & 16.375 & 30.135 & $50-85$ \\
\hline No.30 & 600 & 745 & 760 & 750 & 751.67 & 37.625 & 67.75 & $25-60$ \\
\hline No.50 & 300 & 470 & 495 & 480 & 481.67 & 24.125 & 91.87 & $5-30$ \\
\hline No.100 & 150 & 130 & 150 & 140 & 140 & 7.00 & 98.87 & $0-10$ \\
\hline Pan & & 20 & 25 & 30 & 25 & 1.13 & 100 & \\
\hline SUM & & 2000 & 2000 & 2000 & & 100 & 305.2 & \\
\hline
\end{tabular}

Table-5.2: Sieve analysis of coarse aggregate

\begin{tabular}{|c|c|c|c|c|c|c|c|c|}
\hline \multirow{2}{*}{$\begin{array}{l}\text { ASTM sieve } \\
\text { designation }\end{array}$} & \multirow{2}{*}{$\begin{array}{l}\begin{array}{l}\text { Sieve } \\
\text { size } \\
(\mathbf{m m})\end{array}\end{array}$} & \multicolumn{3}{|c|}{ Weight retained (gm.) } & \multirow{2}{*}{$\begin{array}{l}\text { Retaine } \\
\text { d }(\%)\end{array}$} & \multirow{2}{*}{$\begin{array}{l}\text { Cumulative } \\
\text { retained } \\
(\%)\end{array}$} & \multirow{2}{*}{$\begin{array}{l}\text { Cumulative } \\
\text { passing }(\%)\end{array}$} & \multirow{2}{*}{$\begin{array}{l}\text { Specification \% } \\
\text { passing } \\
\text { (ESC.D3.20) }\end{array}$} \\
\hline & & $\begin{array}{l}\text { Sample } \\
1\end{array}$ & $\begin{array}{l}\text { Sample } \\
2\end{array}$ & $\begin{array}{l}\text { Sample } \\
3\end{array}$ & & & & \\
\hline 3 & 75 & - & - & - & & - & & - \\
\hline 2 & 50 & - & - & - & - & & & - \\
\hline $11 / 2$ & 37.5 & 0 & 0 & 0 & 0 & 0 & 100 & 100 \\
\hline 1 & 25 & 510 & 520 & 515 & 515 & 10.30 & 89.70 & $90-100$ \\
\hline $33 / 4$ & 19 & 2080 & 2260 & 2170 & 2170 & 43.40 & 46.30 & $40-85$ \\
\hline $1 / 2$ & 12.5 & 1780 & 1575 & 1677.5 & 1677.5 & 33.55 & 12.75 & $10-50$ \\
\hline $3 / 8$ & 9.5 & 455 & 465 & 460 & 460 & 9.20 & 3.55 & $0-15$ \\
\hline No.4 & 4.75 & 165 & 175 & 170 & 170 & 3.40 & 0.15 & $0-5$ \\
\hline Pan & & 10 & 5 & 7.5 & 7.5 & 0.15 & 600 & \\
\hline SUM & 5000 & 5000 & 5000 & 5000 & 5000 & 100 & 749.3 & \\
\hline
\end{tabular}


Table-5.3: Specific gravity and water absorption of fine aggregate

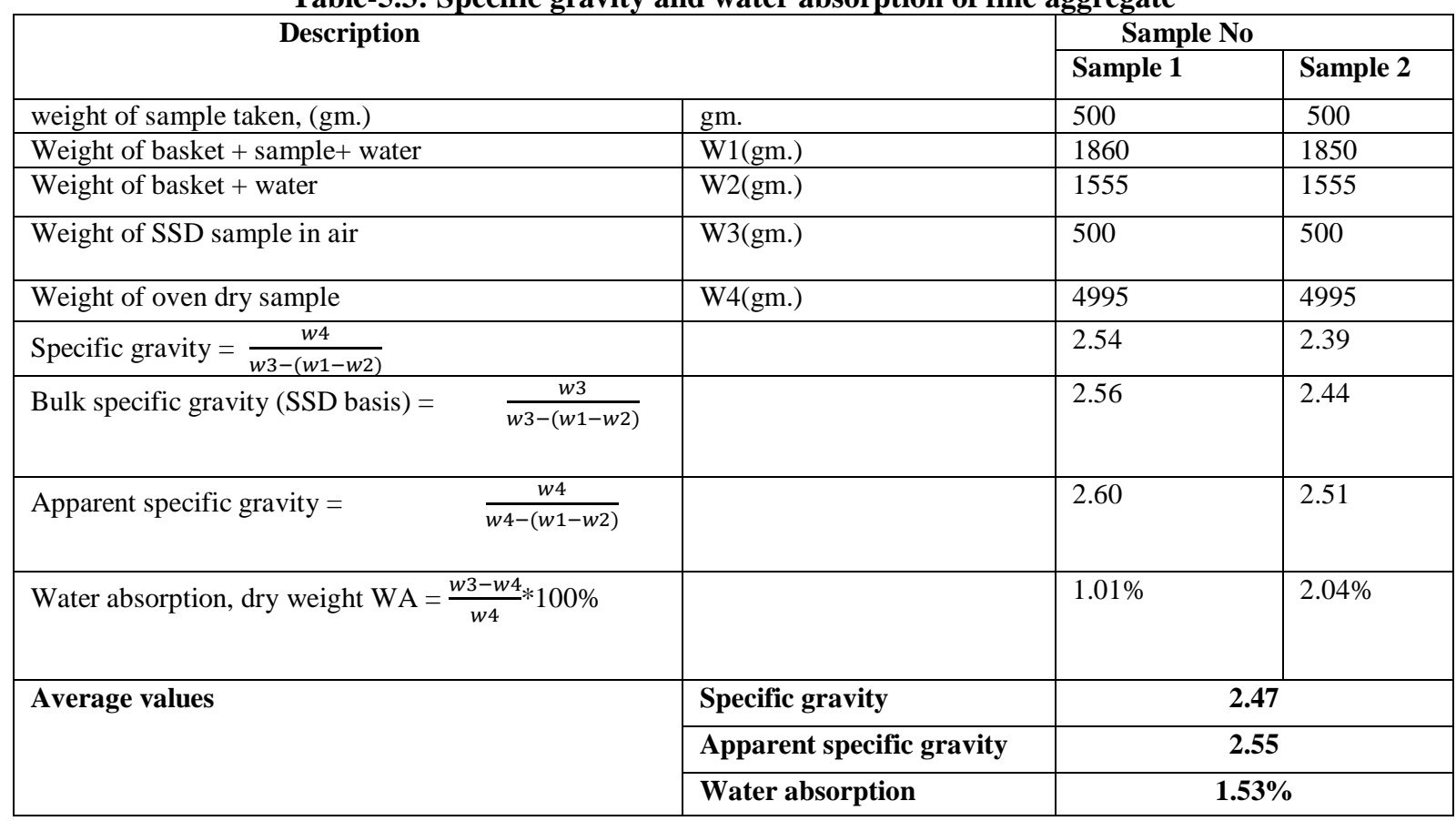

Table-5.3: Specific gravity and water absorption of coarse aggregate

\begin{tabular}{|c|c|c|c|c|}
\hline \multirow{2}{*}{\multicolumn{3}{|c|}{ Description }} & \multicolumn{2}{|c|}{ Sample No } \\
\hline & & & Sample 1 & Sample 2 \\
\hline weight of sample taken, (gm.) & & gm. & 2000 & 2000 \\
\hline Weight of basket + sample+ water & & W1(gm.) & 2329 & 2329 \\
\hline Weight of basket + water & & W2(gm.) & 1260 & 1260 \\
\hline Weight of SSD sample in air & & W3(gm.) & 2005 & 2005 \\
\hline Weight of oven dry sample & & W4(gm.) & 1980 & 1980 \\
\hline Specific gravity $=\frac{w 4}{w 3-(w 1-w 2)}$ & & & 2.66 & 2.66 \\
\hline Bulk specific gravity (SSD basis) = & $\frac{w 3}{w 3-(w 1-w 2)}$ & & 2.56 & 2.44 \\
\hline Apparent specific gravity $=$ & $\frac{w 4}{w 4-(w 1-w 2)}$ & & 2.60 & 2.51 \\
\hline Water absorption, dry weight WA = & $\frac{-w 4}{4} * 100 \%$ & & $1.01 \%$ & $2.04 \%$ \\
\hline \multirow{3}{*}{\multicolumn{2}{|c|}{ Average values }} & Specific gravity & \multicolumn{2}{|c|}{2.66} \\
\hline & & Apparent specific gravity & \multicolumn{2}{|c|}{2.69} \\
\hline & & Water absorption & \multicolumn{2}{|c|}{$1.26 \%$} \\
\hline
\end{tabular}

\section{APPENDIX 3}

\section{MECHANICAL PROPRTIES TEST RESULTS}

- $\quad$ Compressive strength at date 7 
Table-5.4: Mechanical properties test results

\begin{tabular}{|c|c|c|c|c|c|c|c|c|c|c|c|}
\hline \multirow{2}{*}{$\begin{array}{r}\text { Sampl } \\
\text { e }\end{array}$} & \multirow[t]{2}{*}{ Marking } & \multirow{2}{*}{$\begin{array}{c}\text { Age in } \\
\text { days }\end{array}$} & \multicolumn{3}{|c|}{ Dimension(cm) } & \multirow{2}{*}{$\begin{array}{c}\text { Vol } \\
(\mathbf{c m 3})\end{array}$} & \multirow[t]{2}{*}{ Weight kg } & \multirow{2}{*}{$\begin{array}{l}\text { Unit weight } \\
(\mathrm{kg} / \mathrm{cm} 3)\end{array}$} & \multirow{2}{*}{$\begin{array}{c}\text { Press area } \\
(\text { (cm2) }\end{array}$} & \multirow{2}{*}{$\begin{array}{c}\text { Total } \\
\text { load } \\
\text { tons }\end{array}$} & \multirow{2}{*}{$\begin{array}{c}\text { Compressi } \\
\text { ve strength } \\
(\mathrm{kg} / \mathrm{cm} 3)\end{array}$} \\
\hline & & & $\mathrm{L}$ & $\mathrm{B}$ & $\mathrm{H}$ & & & & & & \\
\hline 1 & $0 \%$ & 7 & 15 & 15 & 15 & 3.37 & 8.378 & 2.37 & 225 & 50 & 223.87 \\
\hline 2 & $0 \%$ & 7 & 15 & 15 & 15 & 3.37 & 8.321 & 2.37 & 225 & 51 & 225 \\
\hline 3 & $0 \%$ & 7 & 15 & 15 & 15 & 3.37 & 8.373 & 2.37 & 225 & 50.5 & 224.45 \\
\hline \multicolumn{12}{|c|}{ Average 8.36 $50.5 \quad 220.44$} \\
\hline 1 & $0.5 \%$ & 7 & 15 & 15 & 15 & 3.37 & 8.245 & 2.37 & 225 & 54 & 238 \\
\hline 2 & $0.5 \%$ & 7 & 15 & 15 & 15 & 3.37 & 8.330 & 2.37 & 225 & 53.7 & 239.3 \\
\hline 3 & $0.5 \%$ & 7 & 15 & 15 & 15 & 3.37 & 8.289 & 2.37 & 225 & 53.4 & 238.68 \\
\hline \multicolumn{12}{|c|}{ 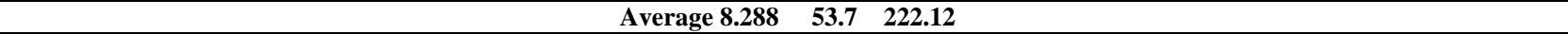 } \\
\hline 1 & $1 \%$ & 7 & 15 & 15 & 15 & 3.37 & 8.20 & 2.37 & 225 & 53 & 239.6 \\
\hline 2 & $1 \%$ & 7 & 15 & 15 & 15 & 3.37 & 8.16 & 2.37 & 225 & 54.8 & 238.23 \\
\hline 3 & $1 \%$ & 7 & 15 & 15 & 15 & 3.37 & 8.288 & 2.37 & 225 & 54 & 241 \\
\hline \multicolumn{12}{|c|}{ 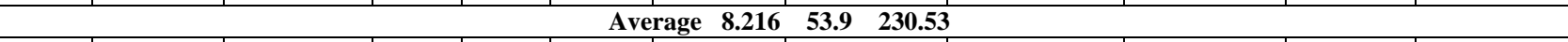 } \\
\hline 1 & $1.5 \%$ & 7 & 15 & 15 & 15 & 3.37 & 8.116 & 2.37 & 225 & 56.4 & 243.19 \\
\hline 2 & $1.5 \%$ & 7 & 15 & 15 & 15 & 3.37 & 8.202 & 2.37 & 225 & 55.2 & 256 \\
\hline 3 & $1.5 \%$ & 7 & 15 & 15 & 15 & 3.37 & 8.113 & 2.37 & 225 & 55.7 & 255 \\
\hline \multicolumn{12}{|c|}{$\begin{array}{llll}\text { Average } & 8.144 & 55.7 & 250.13 \\
\end{array}$} \\
\hline 1 & $2 \%$ & 7 & 15 & 15 & 15 & 3.37 & 8.110 & 2.37 & 225 & 53.5 & 239 \\
\hline 2 & $2 \%$ & 7 & 15 & 15 & 15 & 3.37 & 8.114 & 2.37 & 225 & 54.6 & 240 \\
\hline 3 & $2 \%$ & 7 & 15 & 15 & 15 & 3.37 & 8.064 & 2.37 & 225 & 53 & 237.01 \\
\hline
\end{tabular}

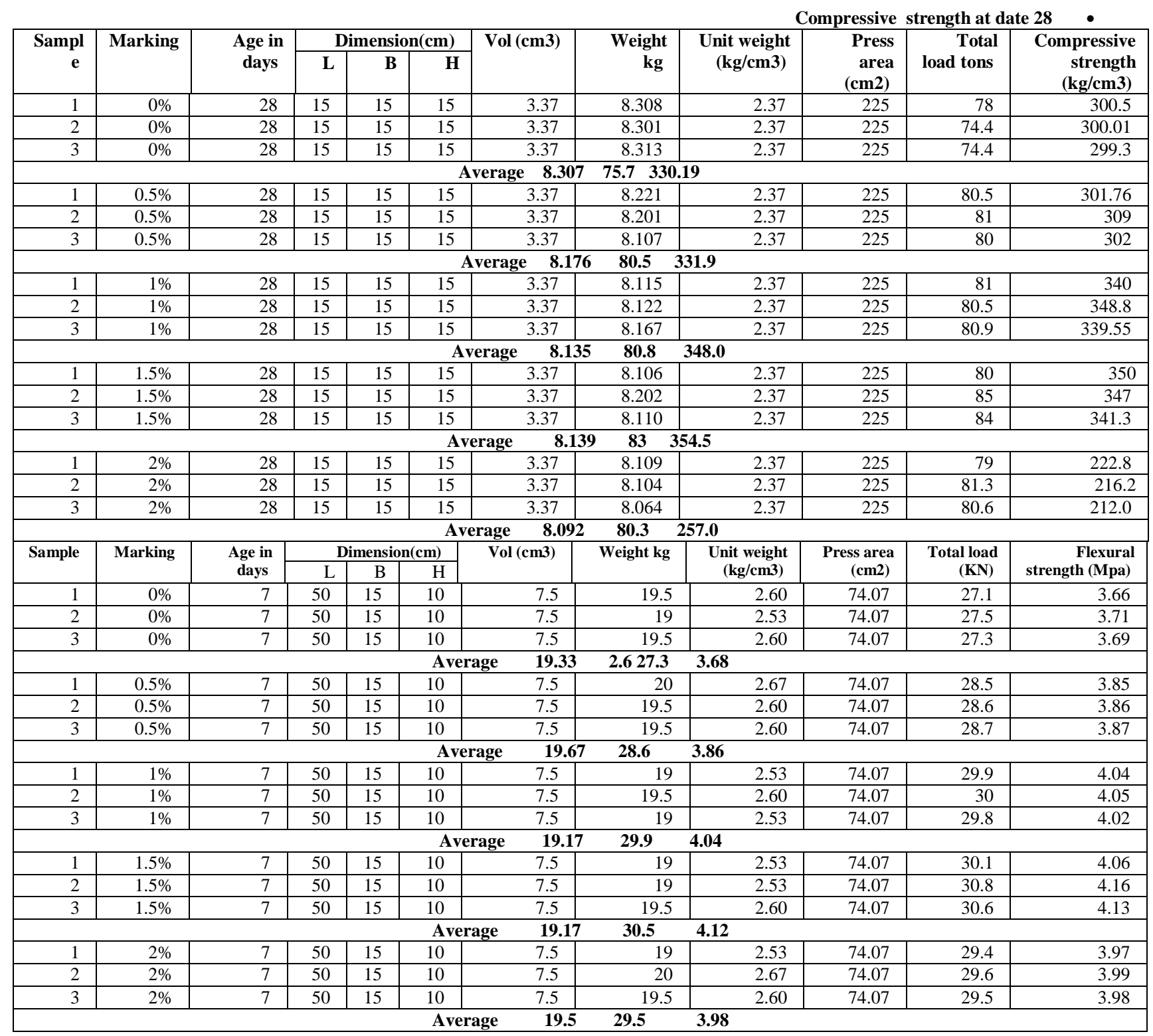




\section{Flexural strength test}

\begin{tabular}{|c|c|c|c|c|c|c|c|c|c|c|c|}
\hline \multirow{3}{*}{ Sample } & \multirow{3}{*}{$\begin{array}{c}\text { Marki } \\
\text { ng }\end{array}$} & \multirow{3}{*}{$\begin{array}{l}\text { Age in } \\
\text { days }\end{array}$} & & \multirow{3}{*}{$\begin{array}{c}\text { Flexural } \\
\text { strength } \\
\text { (Mpa) }\end{array}$} \\
\hline & & & & & Dimension(cm) & \multirow{2}{*}{$\begin{array}{c}\text { Vol } \\
(\mathrm{cm} 3)\end{array}$} & \multirow{2}{*}{$\begin{array}{c}\text { Weight } \\
\text { kg }\end{array}$} & \multirow{2}{*}{$\begin{array}{r}\text { Unit } \\
\text { weight } \\
(\mathrm{kg} / \mathrm{cm} 3)\end{array}$} & \multirow{2}{*}{$\begin{array}{l}\text { Press } \\
\text { area } \\
(\mathrm{cm} 2)\end{array}$} & \multirow{2}{*}{$\begin{array}{c}\text { Total } \\
\text { load } \\
(\mathrm{KN})\end{array}$} & \\
\hline & & & $\mathbf{L}$ & B & $\mathbf{H}$ & & & & & & \\
\hline 1 & $0 \%$ & 28 & 50 & 15 & 10 & 7.5 & 19 & 2.53 & 74.07 & 27.4 & 3.7 \\
\hline 2 & $0 \%$ & 28 & 50 & 15 & 10 & 7.5 & 19 & 2.53 & 74.07 & 27.7 & 3.74 \\
\hline 3 & $0 \%$ & 28 & 50 & 15 & 10 & 7.5 & 19 & 2.53 & 74.07 & 27.7 & 3.74 \\
\hline \multicolumn{12}{|c|}{$\begin{array}{llll}\text { Average } & 19 & 27.6 & 3.73 \\
\end{array}$} \\
\hline 1 & $0.5 \%$ & 28 & 50 & 15 & 10 & 7.5 & 19 & 2.53 & 74.07 & 29.6 & 4.0 \\
\hline 2 & $0.5 \%$ & 28 & 50 & 15 & 10 & 7.5 & 19.5 & 2.60 & 74.07 & 30.4 & 4.1 \\
\hline 3 & $0.5 \%$ & 28 & 50 & 15 & 10 & 7.5 & 19 & 2.53 & 74.07 & 33.3 & 4.5 \\
\hline \multicolumn{12}{|c|}{$\begin{array}{llll}\text { Average } & 19.17 & 31.1 & 4.2 \\
\end{array}$} \\
\hline 1 & $1 \%$ & 28 & 50 & 15 & 10 & 7.5 & 20 & 2.67 & 74.07 & 31.0 & 4.19 \\
\hline 2 & $1 \%$ & 28 & 50 & 15 & 10 & 7.5 & 19.5 & 2.60 & 74.07 & 31.5 & 4.25 \\
\hline 3 & $1 \%$ & 28 & 50 & 15 & 10 & 7.5 & 19.5 & 2.60 & 74.07 & 31.4 & 4.24 \\
\hline \multicolumn{12}{|c|}{$\begin{array}{llll}\text { Average } & 19.67 & 31.3 & 4.22\end{array}$} \\
\hline 1 & $1.5 \%$ & 28 & 50 & 15 & 10 & 7.5 & 19 & 2.53 & 74.07 & 34.8 & 4.7 \\
\hline 2 & $1.5 \%$ & 28 & 50 & 15 & 10 & 7.5 & 19 & 2.53 & 74.07 & 34.5 & 4.66 \\
\hline 3 & $1.5 \%$ & 28 & 50 & 15 & 10 & 7.5 & 19.5 & 2.60 & 74.07 & 34.6 & 4.67 \\
\hline \multicolumn{12}{|c|}{\begin{tabular}{llll|} 
Average & 19.17 & $\mathbf{3 4 . 6 3}$ & 4.68
\end{tabular}} \\
\hline 1 & $2 \%$ & 28 & 50 & 15 & 10 & 7.5 & 19 & 2.53 & 74.07 & 29.1 & 3.93 \\
\hline 2 & $2 \%$ & 28 & 50 & 15 & 10 & 7.5 & 19.5 & 2.60 & 74.07 & 29.5 & 3.98 \\
\hline 3 & $2 \%$ & 28 & 50 & 15 & 10 & 7.5 & 19.5 & 2.60 & 74.07 & 29.6 & 3.99 \\
\hline
\end{tabular}

\section{APPENDIX 4}

Sample photo gallery taken during the research

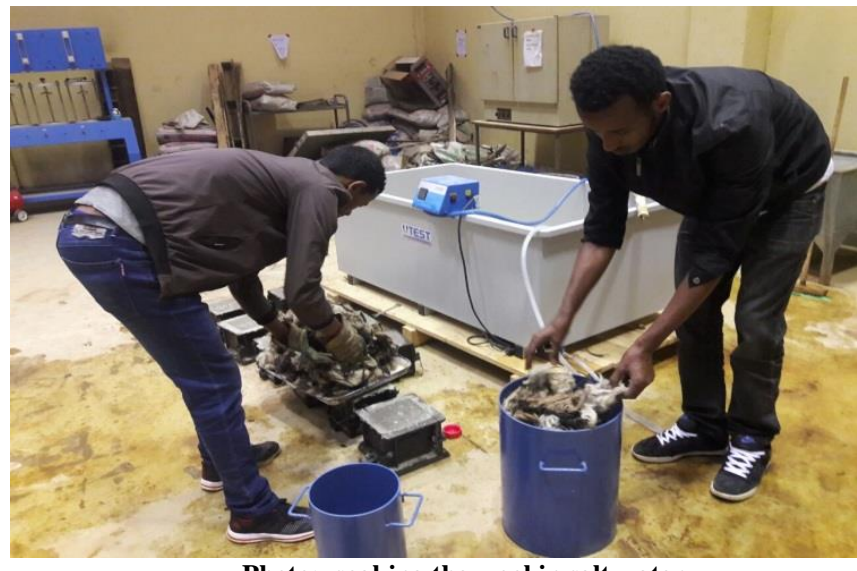

Photo: soaking the wool in salt water

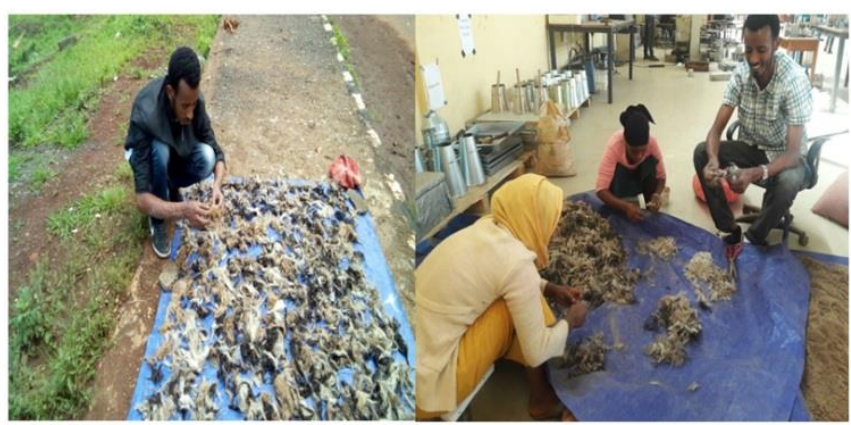

Photo: Sun dry and splaying balling of the wool

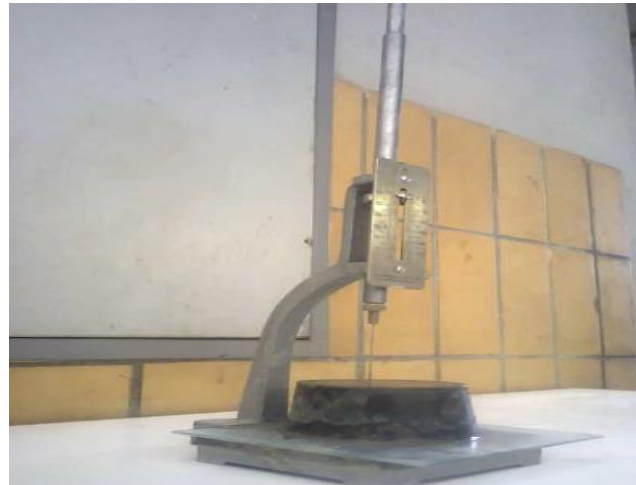

Photo: Initial and final setting time tests for cement

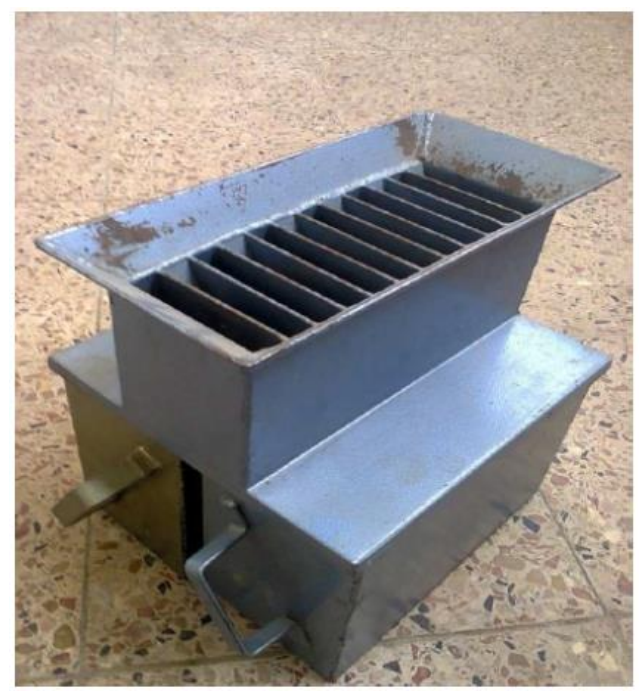

Photo: Riffle Box for quartering fine aggregates and sieves Shaker with series of sieves 


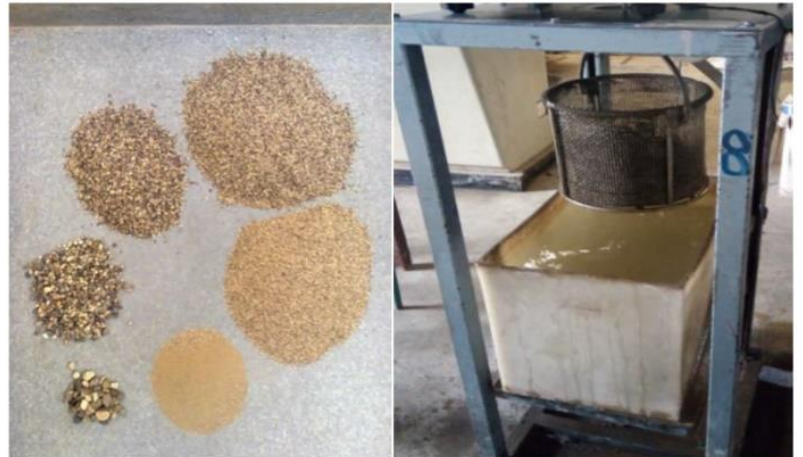

Photo: Graded fine aggregate sample and testing of absorption test

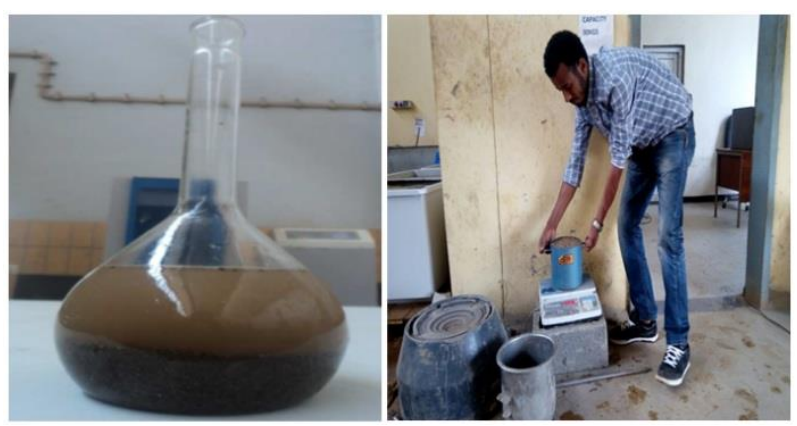

Photo: Test for fine aggregate

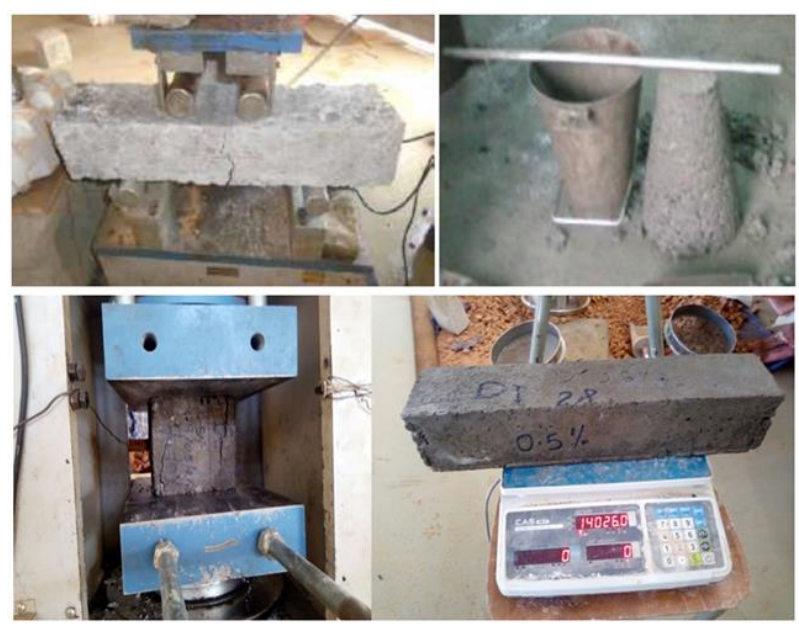

Photo: Test on hardened and fresh concrete

Advisor: Ing. Getachew Kebede (Ph.D. Candidate, Assistant Professor)

Co - Advisor: Ing. Lucy Feleke (Ph.D. Candidate)

\section{REFERENCES}

1. Hamito. D. (2009). Sheep breeds of Ethiopia: A guide for identification and utilization. Ethiopia: Ethiopia Sheep and Goat Productivity Improvement Program.

2. Naveen Kumar T, K. G. (2015). An Experimental Study on Mechanical Properties of Human Hair Fibre Reinforced Concrete (M-40 Grade). IOSR Journal of Mechanical and Civil Engineering (IOSR-JMCE, 65.

3. Saxena, M., P. A. (2011). Composite Materials fromNatural Resources: Recent Trends and Future
Potentials. (P. Těšinova, Ed.) Advances in Composite Materials - Analysis of Natural and Man-Made Materials.

4. Mugure WN. (2014). Investigation of the performance of natural fibres as a micro reinforcement in concrete. Nairobi: university of Nairobi.

5. DArcy. N.B. (1986). Sheep and wool technology. NSW University press, kensing, 106-4.

6. North Adams, M. (2009). Storey's Guide to Raising sheep. Storey publishing, pp 315-316.

7. Vishal Gadgihalli, M. C. (2017). Analysis of properties of concrete using sheep wool dipping in salt water as fibre reinforcement admixture. International Journal of Research - Granthaa, 5759.

8. Ganiron, T. U. (2014). Effects of Human Hair Additives in Compressive Strength of Asphalt Cement Mixture. International Journal of Advanced Science and Technology, 12.

9. Bogale, B. (2007). Comparision of concrete durablity as produced by various cements manufactured in Ethiopia. Ethiopia: Addis Ababa University.

10. Pavankumar, A. D. (2017). An Experimental Investigation on HumanHair Fibre Concrete. International Journal of Innovative Research in Science, Engineering and Technology, 435.

11. Kothari, J. D. (2014). Hair fiber reinforced concrete. Composite Materials from Natural Resources: Recent Trends and Future Potentials.

12. Tuzcu, T. (2016). Hygro-Thermal Properties of Sheep Wool Insulation. Thesis, Civil Engineering.

13. Bentur A, M. S. (2006). Fiber Reinforced Cementitious Composites, Second Edition: Rout ledge;

14. Lufgren, I. (2005). Fiber - reinforced Concrete for Industrial Construction a fracture mechanics. Chalmers University of Technology.

15. Nemati, P. K. (2015). Fiber Reinforced. Concrete thecnology. washington: Professor Kamran M. Nemati.

16. Betterman, L.R.O. C. (1995). Fiber - matrix interaction in micro fiber - reinforced mortar Advanced Cement Based Materials, 2(2), 53- 61.

17. Silva, F. E. (2007). Behaviour of CRBP-AL Composites Subjected To Impact Load, in 17th ASCE. Engineering Mechanics Conference Delaware.

18. Rui Zhong, K. W. (April 2016). Compression response of normal and high strength pervious concrete. Construction and building materials, 109, 15.

19. Rahman, H. A. (2012). Some properties of fibre reinforced no fine concrete. Al-Qadisiya journal for engineering science.

20. Gopinath. A., A. D. (2017). Fibre Reinforced Pervious Concrete Using Banana Fibre. International Journal of Engineering and Management Research, 7(2), 127-132. 
21. Concrete, F. R. (2001, January 15). http://abandiI.1st.net/fibremsh.htm,.

22. Jorillo. P. Jr., \& G. Shimizu. (1992). Coir fibre reinforced cement based composites. Part two: Fresh and mechanical properties of fiber concrete. Proc., Fourth RILEM International Symposium on Fiber Reinforced Cement and Concrete, (pp. pp. 1096 - 1109). Ed., R.N. Swamy, London:E and FNSpon.

23. F.M, L. (1970). The chemistry of cement and concrete, 3rd ed (3rd edition ed.). Edward Arnold Ltd.

24. Neville. A.M. (1981). Properties of Concrete, (3rd edition ed). London: Pitman Publishing Ltd.

25. ASTMC33/C33M. (2011). standard specification for concrete aggregates ASTMC33/C33M-11. In ASTMC33/C33M. USA.

26. ASTEM American Society for Testing and Materials. (2002). Annual Book OF ASTM Standards. In Section 04.02 - Concrete and Aggregates. Printed IN Baltimore, MD.
27. Kuder. K.G. (2007). "Rheology of fiber reinforced cementitious materials". Cement and Concrete research, 37, $191-199$.

28. ESA. (2013). composition, specification and conformity criteria for common cement (first edition ed., Vol. CES 28). A.A: ESA.

29. ACI318M. (2011). standard specification for concrete aggregates.

30. Ketema, A. (2010). The use of recycled rubber tires as a partial replacment for coarse aggregate in concrete construction. Civil engineering. Addis Ababa University.

31. Abraham, N. S., Hlatky, M. A., Antman, E. M., Bhatt, D. L., Bjorkman, D. J., Clark, C. B., ... \& Mahaffey, K. W. (2010). ACCF/ACG/AHA 2010 expert consensus document on the concomitant use of proton pump inhibitors and thienopyridines: a focused update of the ACCF/ACG/AHA 2008 expert consensus document on reducing the gastrointestinal risks of antiplatelet therapy and NSAID use. Journal of the American College of Cardiology, 56(24), 2051-2066. 